Historic, Archive Document

Do not assume content reflects current scientific knowledge, policies, or practices. 

WOODIAAWN NURSERIES

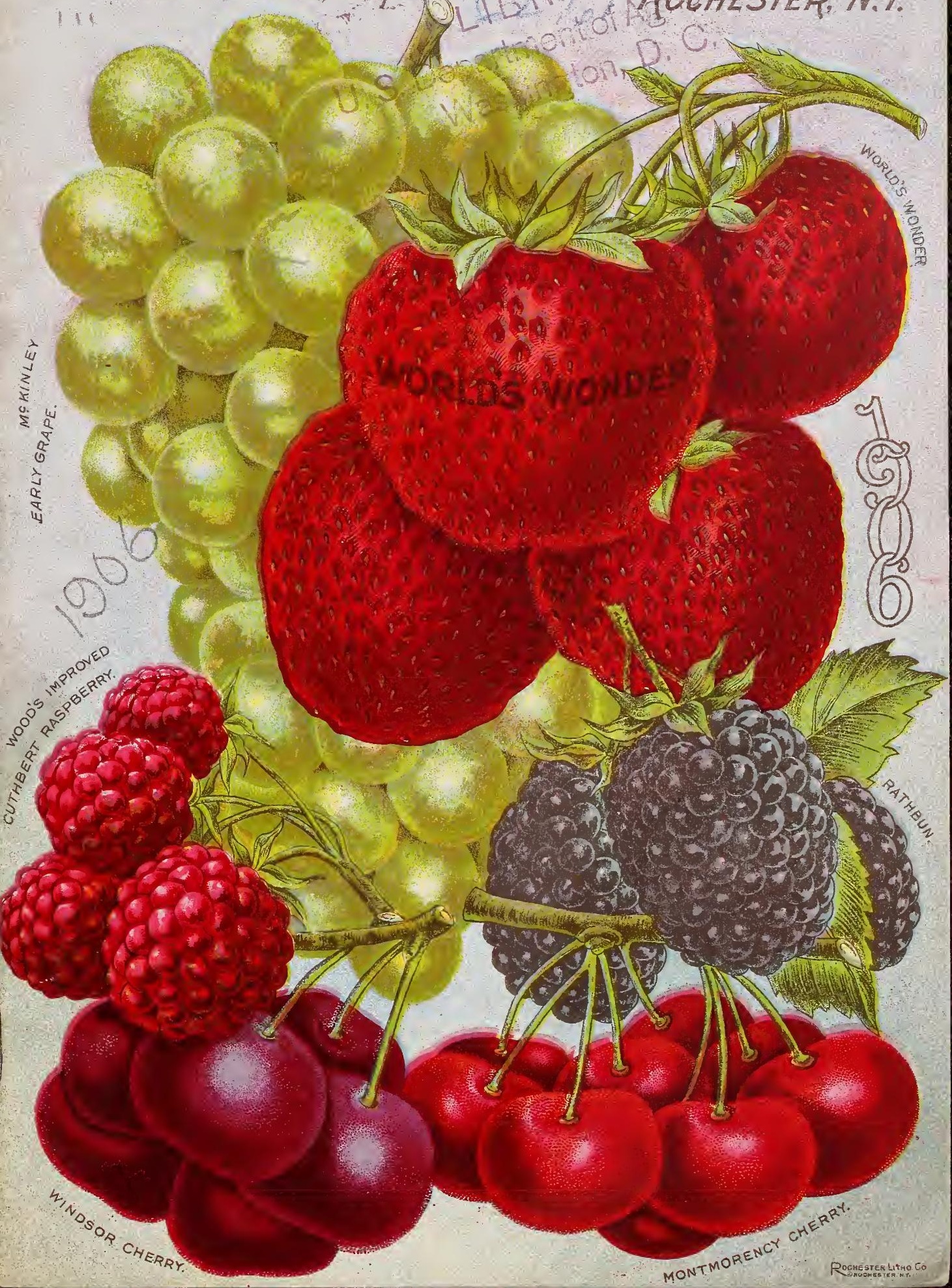




\section{Facts About Our Business}

THIRTY YEARS AG0 ALLEN L. WOOD started in the nursery business on one acre of land. He promised himself to sell only the best plants in the world, or he would not sell any. The result of his perseverance has been the establishment of the largest mail order business of its kind in the United States.

It was in the Cent...nial year that Mr. Wood started to do a wholesale business in small fruit plants. He named his nurseries the Woodlawn Nurseries, and any plants or trees bearing this name are guaranteed to be the best grown.

In the year I88I Mr. Wood had ten acres of land under cultivation, and this increased to seventy-five acres by $189 \mathrm{I}$. In I 900 he had one hundred eighteen acres under cultivation, which was necessary to produce the plants to keep pace with the orders of his ever increasing business.

It was in the year I89o that he was called "King of Small Fruit Growers," because he grew more small fruit plants than any three nurserymen in the country put together.

Up to $1900 \mathrm{Mr}$. Wood was strictly in the wholesale business, devoting his entire time to the growing of small fruit plants, and having made a success of the wholesale branch of the business, he decided at that time to send out a retail catalogue for express and mail orders. From an insignificant beginning, when he only had one customer in a village or township, he now has 100,000 customers, scattered all over the states and territories.

This shows what close attention to business has done for him, and the confidence his patrons have placed in his guarantee, that goes with all shipments of nursery stock. Many orders are received from foreign countries, and the mail order department of the business alone requires a large number of trained assistants.

Mr. Wood continues to grow all of his own trees and Roses, and is therefore sure that they are vigorous, hardy and true to name.

A nursery business that has been built up from nothing and has grown to the largest of its kind in the world, is a recommendation in itself to intending purchasers.

If you have perfect plants to start with, grown strong and hardy, you are pretty sure of getting big crops, and it is better to begin right by buying right on the start, without experimenting, and thereby losing time and money.

Begin right this year, and buy your nursery stock from the Woodlawn Nurseries, Rochester, N. Y.

The financial standing of the Woodlawn Nurseries is quoted in Dun's or Brad street's mercantile reports, which may be seen in any bank or large business house in the country.

\section{THE WOODLAWN NURSERIES}

ROCHESTER, N. Y. 


\section{ORDER SHEET--PINASE USE THIS SHEET No.}

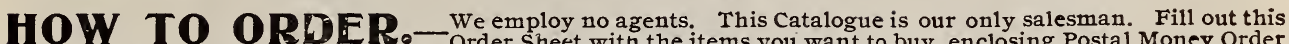
- Order Sheet with the items you want to buy, enclosing Postal Money Order or Bank draft on New York, and mail all to us in enclosed envelope. By this method you save half the money you would have to pay agents tor trees. We have filled orders in this way for thirty years, and are well known all through the country. You can learn of our resporsibility through any commercial agency, bank or banker, or of the postmaster at Rochestcr, iN. Y. We pack and ship all Winter to Southern States. Our regular Spring Shipping Season opens ebout March I5. State positively how we are to ship, whether by Freight, Express or Mail. If by Freighi cr Express, give name of R. R. station and your post-office.

\section{ALLEN L. WOOD, Rochester, N. Y.}

Name

Post: Office

County

State.

Be sure to give the name of Express Office if desired by Iixpress, or Freight Station if desired by Freight. Also name your Post Office Address.

Express Office

Freight Station.

Express Co.

Railroad

Quantity

OUR GUARANTEE. While we exercise the greatest care to have our stock genuine and reliable, we agree to replace on proper proof, all that may prove untrue to name as labelled, and it is hereby mutually agreed that our replacing it or offer to replace it shall operate as a liquidation of all damages. 


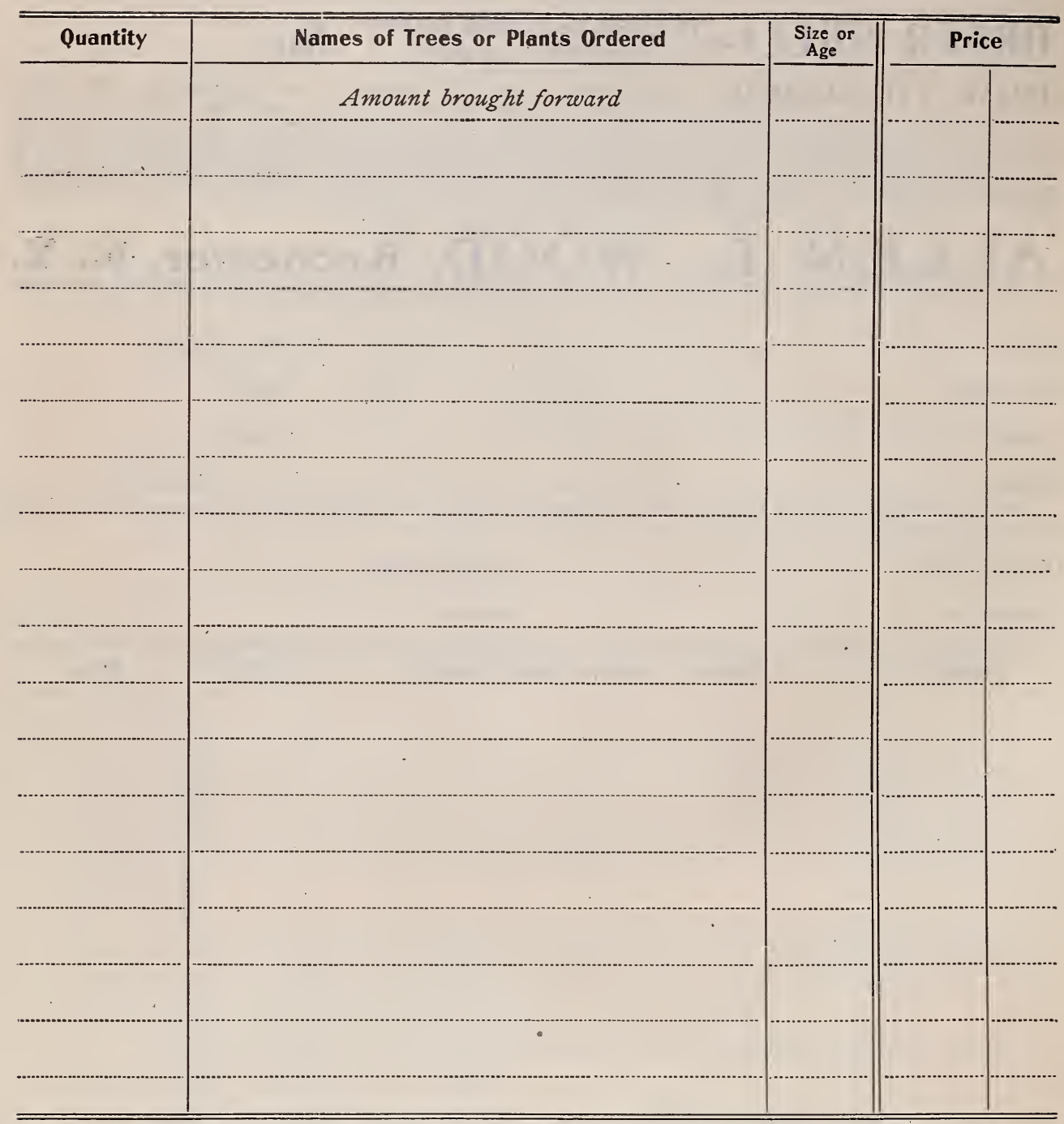

Please write below the names and address of a few of your friends who are interested in and buyers of TREES, PLANTS, ETC. 


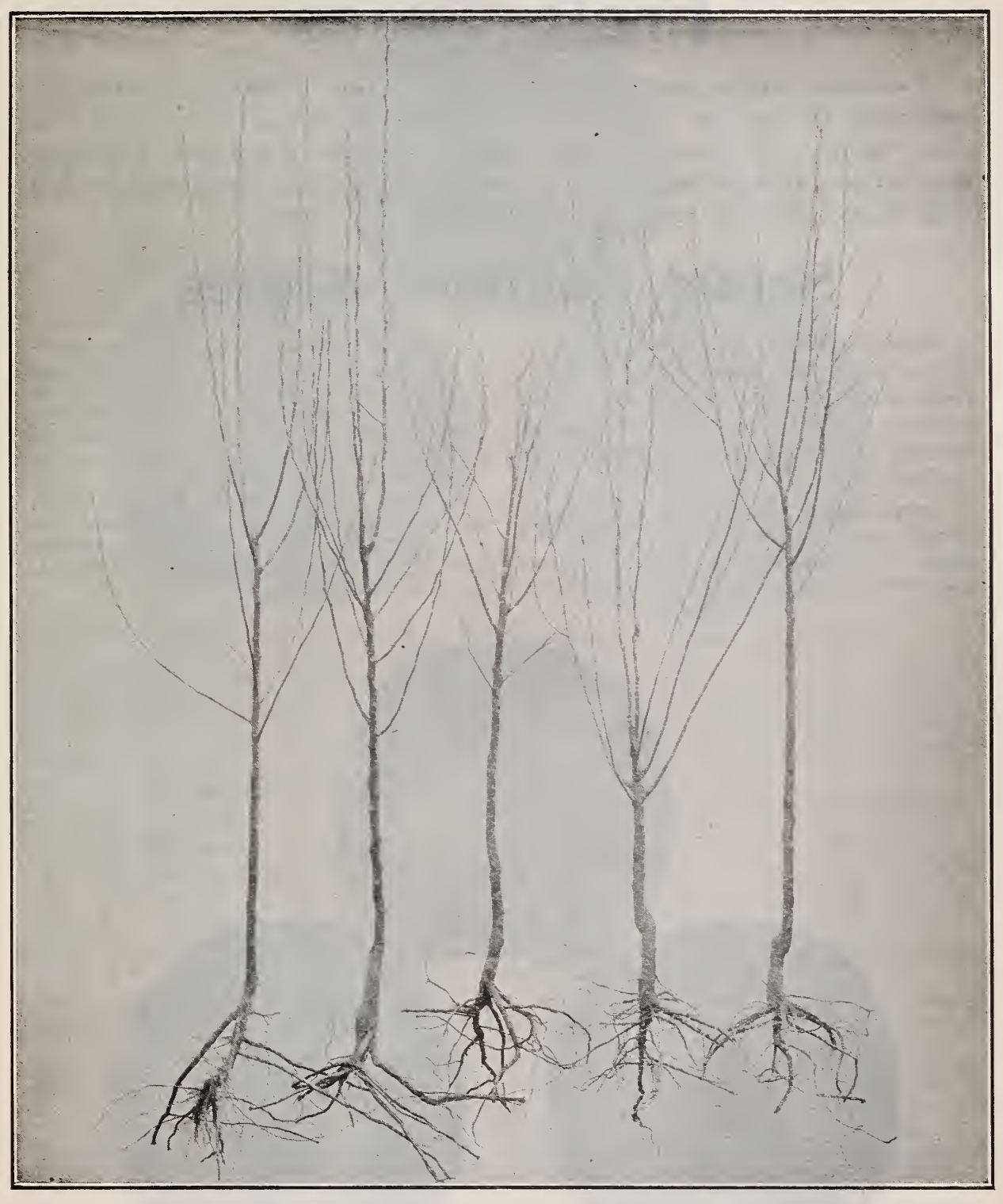

1

23

4

5

The kind of trees we send out. No. I, Baldwin apple; No. 2, Bartlett pear, No. 3 ; Montmorency cherry; No. 4, Abundance plum; No. 5, Crawford Early peach.

You can save from $\$ 50$ to $\$ 100$ in buying your trees of us. We grow the trees ourselves and they go direct from us to you. We do not employ any agents to sell our trees for us, the trees themselves are all the agents we need. When you buy our trees, you pay the actual cost of growing and our very small profit, and not some agent's exorbitant price. We sell thousands of trees every year, but an agent may only sell a hundred, and he must charge you enormous prices in order to meet his expenses. Since we grow our own trees we know they are true to name. 


\section{Fruit Trees}

Varieties of Apples named are beyond doubt the most profitable for market and best bearers for home use. You run no risk whatever in making your selections from these. Our trees will please you. Price of Choice Apple Trees, 2 to 3 years, 5 to 6 feet high, 15c. each, $\$ 1.50$ per dozen, $\$ 11.00$ per $100, \$ 100.00$ per 1,000. Extra size 6 to 7 feet high, 20c. each, $\$ 2.00$ per dozen, $\$ 15.00$ per $100, \$ 125.00$ per 1,000 .

\section{Select Summer Apples}

Early Harvest-Medium to large size; pale yellow; tender, with a mild, fine flavor. Tree a moderate, erect grower, and a good bearer; a beautiful and excellent variety for both orchard and garden, being one of the first to ripen.

Sweet Bough (Large Yellow Bough) Large; pale yellow; sweet, tender and juicy. Tree a moderate, compact grower and abundant bearer.
Red Astrachan-Large, roundish, nearly covered with deep crimson, overspreał with a thick bloom; very handsome; juicy, good, though rather acid. The tree is very hardy, a free grower, with large foliage, and a good bearer; highly esteemed on account of its fine appearance.

Yellow Transparent-A Russian apple; medium size, roundish, oblate, slightly conical; skin pale yellow when fully mature; flesh juicy, tender, sprightly, sub-acid; good; a free grower.

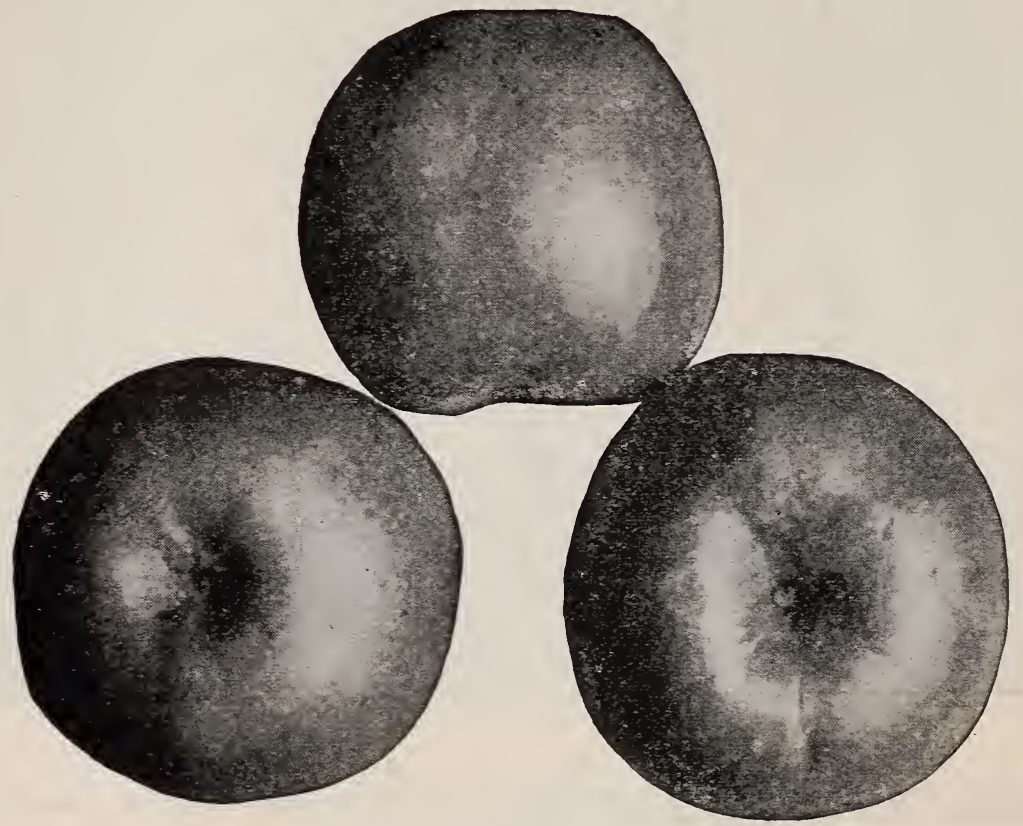

Fall Pippin. One of the old household favorites.

\section{Select Fall Apples}

Fall Pippin-Very large, roundish, oblong; yellow; flesh tender, rich and delicious. Tree a free grower, spreading, and fine bearer; one of the most valuable varieties for table or market. An admirable baking apple. Extensively grown in Western New York as Holland Pippin. 


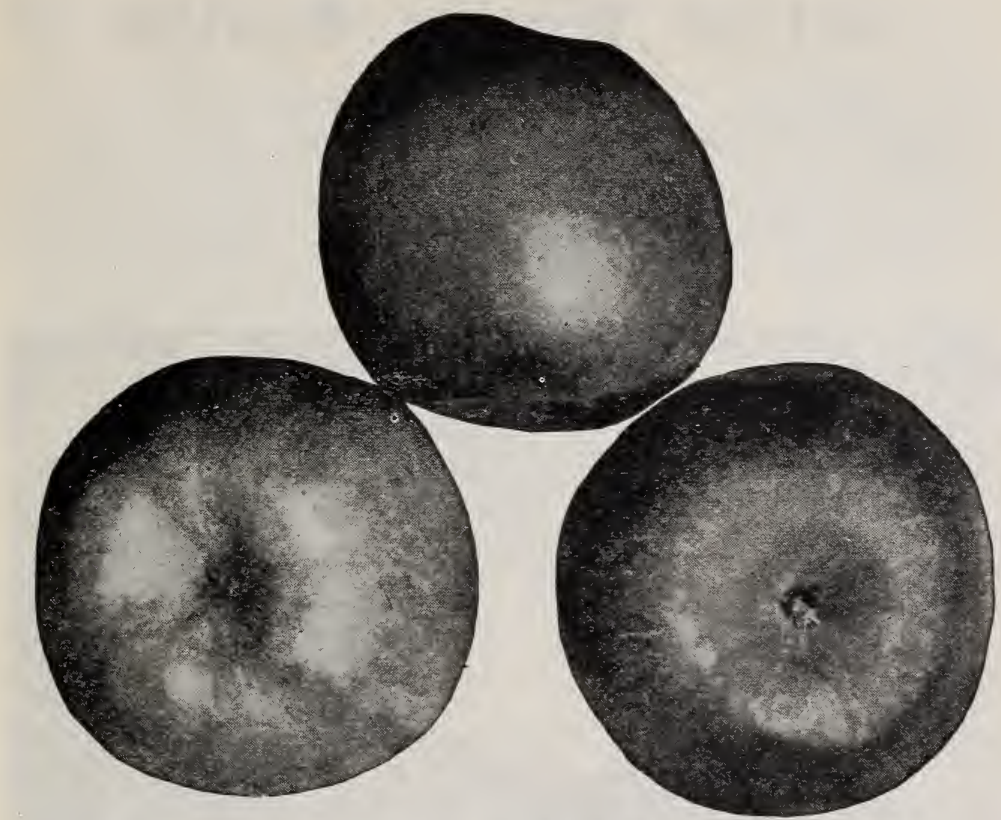

York Imperial. Prized in Pennsylvania as a winter apple.

Chenango (Chenango Strawberry, Sherwood's Favorite)-Large, oblong; red and yellow; very handsome; highly valued as a table or market fruit on account of its handsome appearance and fair quality. Tree a vigorous grower and very productive.

Prompt Attention.
Michigan, May 4, 1905.
Dear Sir:-I received in good con-
dition the tree you shipped to replace
broken one and I thank you very much
for your prompt attention. Any time
you care to send us catalogues, we
shall be pleased to distribute them
among the farmers.
Yours very truly,
LAUHOFF BROS.
Trees Nice and Thrifty.
New York, May 2, 1905.
Dear Sir:-Trees and plants received.
must say the stock was very fine.
Trees were nice and thrifty and plants
are large and well rooted.
Respectfully,
W. F. BUCKLAND.
Plants Very Fine.
West Virginia, April 29, 1905.
Dear Sir:-I received the trees all
O. K. They were very fine.
Respectfully,
MRS. BARTLEY CAMPBELL.

Gravenstein-A very large, striped, roundish apple of the first quality. Tree remarkably rapid, vigorous and erect in growth, and very productive. One of the finest fall apples.
Maiden's Blush-Large, flat; pale yellow with a red cheek; beautiful; tender and pleasant, but not high-flavored. Tres an erect, free grower and a good bearer. A valuable market apple.

Oldenburg (Duchess of Oldenburg)A large, beautiful, Russian apple; roundish; streaked red and yellow; tender, juic $y^{\prime}$ and pleasant. A kitchen apple of best quality, and esteemed by all for the dessert. Tree a vigorous, fine grower, and a young and abundant bearer. Very hardy. Succeeds well in the Northwest, where most varieties fail.

Red Bietigheimer-A rare and valuable German variety. Fruit large to very large; roundish, inclining to conical; skin pale, cream colored ground, mostly covered with purplish crimson; flesh white, firm, sub-acid, with a brisk, pleasant flavor. Tree a free grower and abundant bearer. This is one of the largest and handsomest apples, and worthy of extensive cultivation.

Red June-Medium size; deep red; flesh white, tender, juicy, sub-acid. Prolific bearer.

Twenty Ounce-A very large, showy, striped apple. Tree a free grower and fine bearer; excellent for baking.

Wealthy-Originated near St. Paul, Minn. Fruit medium, roundish, skin smooth, oily, mostly covered with dark red; flesh white, fine, juicy, vinous, subacid, very good. Tree very hardy, a free grower and productive. A variety of much value on account of its great hardiness and good quality. 


\section{Select Winter Apples}

Arkansas Black-Medium to large; dark red; fine-grained, pleasant sub-acid. Of best quality. A seedling of Winesap, resembling it in fruit, but much larger.

King-A superb red apple of the largest size and finest quality. Tree a vigorous grower and good bearer; hardy.
Fameuse (Snow Apple)-Medium size; deep crimson; flesh snowy white, tender, melting and delicious. Tree vigorous, with dark wood; one of the finest dessert fruits, and valuable for market; succeeds particularly well in the North.

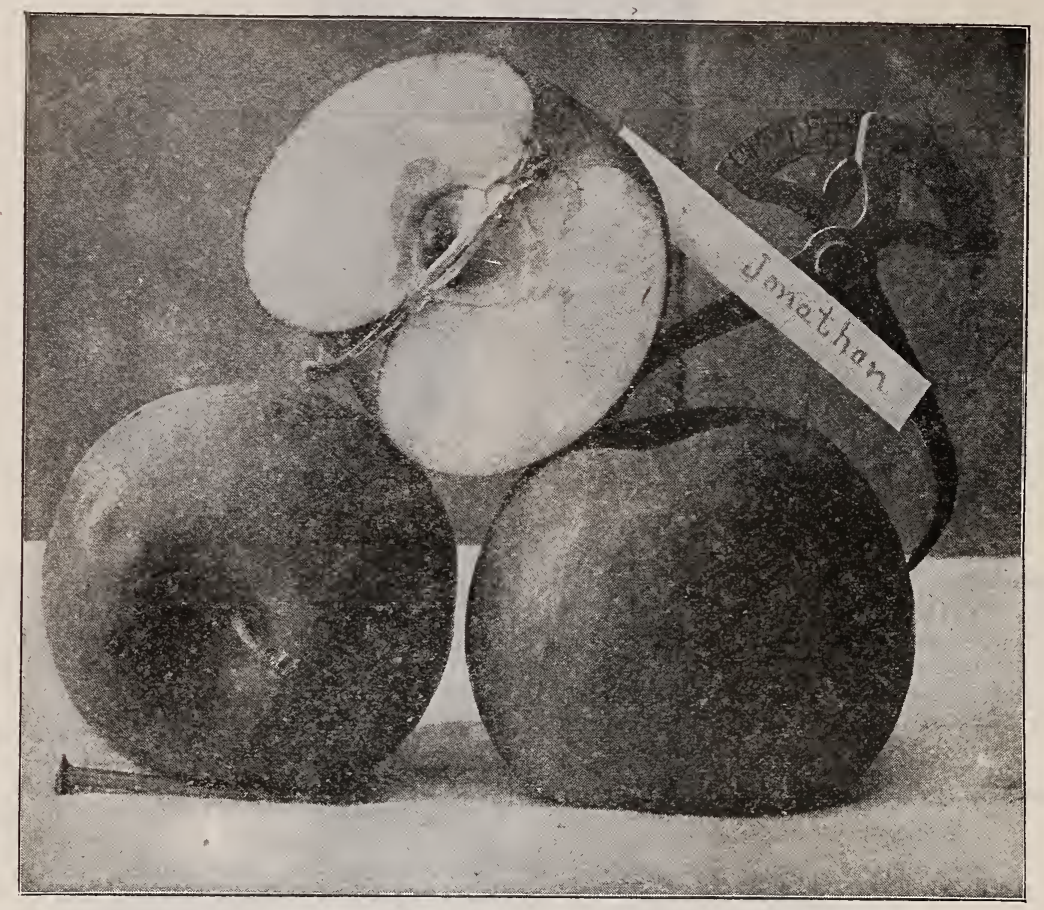

Jonathan. Combines high quality and handsome appearance.

\section{See Bargain Price on Jonathan Apple}

Jonathan-Medium; deep red, high quality. Early and abundant bearer; productive. An excellent family apple and widely profitable for market, selling at highest prices.

Reduced price on Jonathan apple trees, first class, 2 to 3 years, 5 to 6 feet high, 10c. each, $\$ 1.00$ per dozen, $\$ 8.00$ per 100 . Extra size, 6 to 7 feet high, 15c. each, $\$ 1.50$ per dozen, $\$ 11.00$ per 100 .

Gano-Well tested. Fully equal to Ben Davis in productiveness and size. Brilliant red; fair quality; late keeper.

Stayman Winesap-Large; roundish; deep red; medium quality; keeps well. Tree a moderate grower and good bearer; succeeds well in the West, and is there valuable and popular. Not grown here in orchards.
Golden Russet-Medium size, dull russet, with a tinge of red on the exposed side; flesh greenish, crisp, juicy and highflavored. Tree a vigorous grower, with light-colored speckled shoots, by which it is easily known; hardy, bears well; popular and extensively grown in Western New York and Wisconsin.

Grimes' Golden (Grimes' Golden Pippin)-Medium to large size; skin golden yellow sprinkled with gray dots; flesh crisp, tender, juicy, sprightly, very good to best. Tree hardy, vigorous, productive; grown in the South and Southwest.

Hubbardston (Hubbardston Non-such) -Large; striped yellow and red; tender, juicy and fine; a free grower and great bearer. One of the best. 


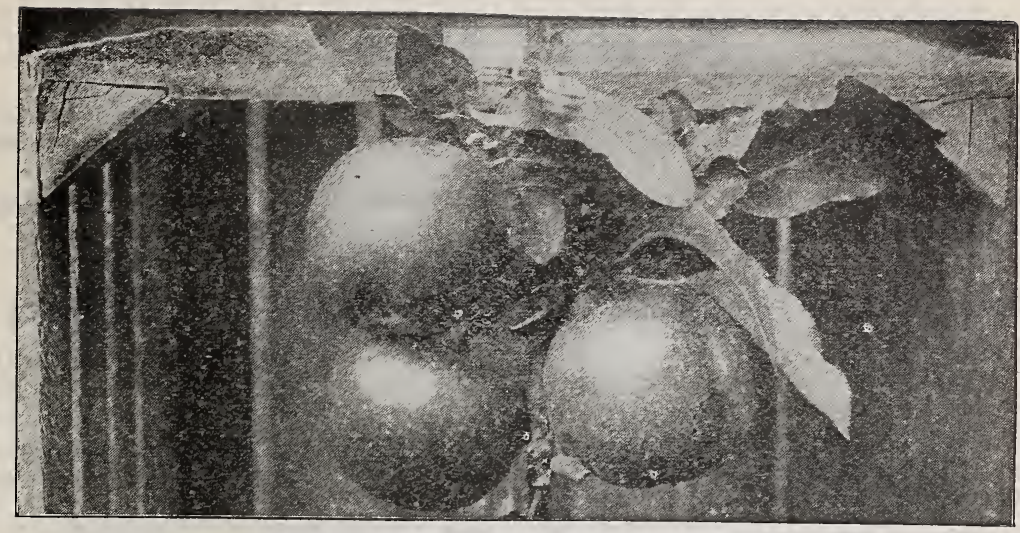

Baldwin. The standard apple of Western New York.

Baldwin-Large, bright, red, crisp, juicy and rich. Tree vigorous, upright and productive. In New England, New York, Ontario and Michigan this is one of the most popular and profitable sorts for either table or market.

McIntosh Red-Large, roundish, skin mostly covered with bright red; flesh white, tender, sub-acid, sprightly, very good. A handsome apple of fine quality. Tree vigorous and hardy.

Northern Spy-Large, striped and quite covered on the sunny side with dark crimson, and delicately coated with bloom. Flesh juicy, rich, highly aromatic, retaining its freshness of appearance and flavor till July. The tree is a remarkably rapid, erect grower and a great bearer. Like all trees of the same habit, it requires good culture and occasional thinning out of the branches to admit the sun and air fully to the fruit. Both leaf and blossom buds open a week later than other varieties. One of the finest late-keeping apples.

Rambo-Medium size; streaked and mottled yellow and red; tender, juicy, mild flavored. Tree a vigorous grower and a good bearer. A widely cultivated and esteemed old variety.

Rhode Island Greening-Everywhere well known and popular; tree spreading and vigorous; always more or less crooked in the nursery; a great and constant bearer in nearly all soils and situations; fruit rather acid, but excellent for dessert and cooking.

Rome Beauty-Large; yellow and bright red; handsome; redium quality; $\mathrm{x}$ moderate grower; good bearer.

Roxbury Russet-Medium to large; surface rough; greenish covered -with russet. Tree a free grower, spreading, and a great bearer; its great popularity is owing to its productiveness and long keeping.

Ben Davis (New York Pippin, Kentucky Streak, etc.)-A large, handsome, striped apple, of good quality. Tree very hardy, vigorous and productive; a late keeper; highly esteemed in the West and Southwest.

Reduced price on Ben Davis apple trees, first class, 2 to 3 years, 5 to 6 feet high, 10c. each, $\$ 1.00$ per dozen, $\$ 8.00$ per 100. Extra size, 6 to 7 feet high, 15c. each, $\$ 1.50$ per dozen, $\$ 11.00$ per 100 .

Sutton Beauty-Fruit medium to large. Tree a free, handsome grower and productive. One of the most valuable market varieties in Western New York.

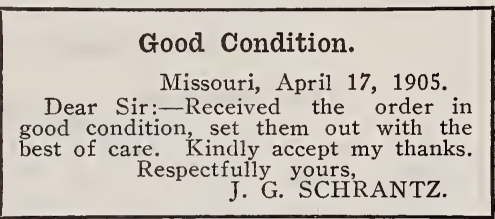

Tolman's Sweet-Medium size; pale whitish yellow, rich and very sweet; excellent for cooking. Very productive.

York Imperial-Medium; whitish, firm, crisp, juicy, pleasant, mild, sub-acid. Tree moderately vigorous and productive. Very popular in Pennsylvania.

Willow Twig-Large; greenish yellow, striped with dull red; early bearer.

\section{Crab Apples}

Price of choice Crab Apple trees, 2 to 3 years, 5 to 6 feet high, 20c. each, $\$ 2.00$ per dozen. Extra size, 6 to 7 feet high, 25c. each, $\$ 2.50$ per dozen.

Hyslop's-Almost as large as the Early Strawberry Apple; deep crimson; very popular in the West on account of its large size. Tree remarkably vigorous.

Transcendent-A beautiful variety of the Siberian Crab; red and yellow. Tree a remarkably strong grower. 


\section{Select Pears}

Price of Standard Pears, first class trees, 2 to 3 years, 5 to 6 feet high, 20c. each, $\$ 2$ per dozen, $\$ 15$ per 100. Extra size, 6 to 7 feet high, 25c each, $\$ 2.50$ per dozen, $\$ 18^{\prime}$ per 100.

Price of Dwarf Pears, first- class trees, 2 to 3 years, 3 to 4 feet high, 15c. each, $\$ 1.50$ per dozen, $\$ 10$ per 100. Extra size, 18c. each, $\$ 1.75$ per dozen, $\$ 12$ per 100 .

\section{Summer Pears}

Bartlett-One of the most popular pears; large, buttery and melting, with a rich flavor. A vigorous, erect grower; bears young and abundantly.

Clapp's Favorite-A splendid pear, resembling the Bartlett, and ripening a few days earlier; the tree is hardy and vigorous.

Tyson-Rather above medium size; melting, juicy, sweet. Tree a very vigorous and rapid grower; bears abundantly every year; one of the best summer varieties.

Wilder-Medium or rather small, regular in form; greenish-yellow with a brownish-red cheek. Tree, a vigorous grower and great bearer.

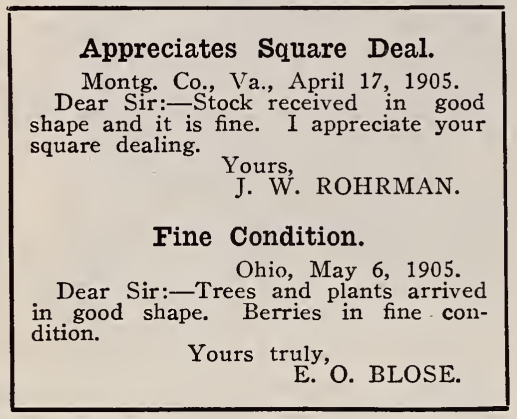

\section{Autumn Pears}

Duchess-One of the largest of all our good pears. As a dwarf it is one of the most profitable of market pears.

Flemish Beauty-A large sweet pear. Tree very hardy, vigorous and fruitful; succeeds well in most parts of the country.

Howell-One of the finest of American pears. Large, yellow and handsome. Tree very vigorous, hardy and productive.

Keiffer-Large; skin rich golden yellow; flesh slightly coarse, juicy, melting, with a pronounced quince flavor. Tree very vigorous and an early and great yielder.

Seckel-The standard of excellence in the pear; small, but of the highest flavor. Tree a stout, slow, erect grower.

Sheldon-A pear of the very first quality. Tree vigorous, erect and handsome, and bears well.

\section{Winter Pears}

Anjou-A large, handsome pear, buttery and melting; keeps into midwinter. Tree a vigorous grower and good bearer.

Clairgeau-Very large, handsome and attractive; flesh yellowish; keeps sound a long time after being gathered. Tree $a$ free grower and an early bearer; valuable for market fruit.

Lawrence-Size medium to large; golden yellow. Tree a moderate grower and an abundant bearer.

Vermont Beauty-Medium size; yellow, covered on sunny side with bright carmine red; rich, juicy, sub-acid. Ripens immediately after Seckel. Very hardy.

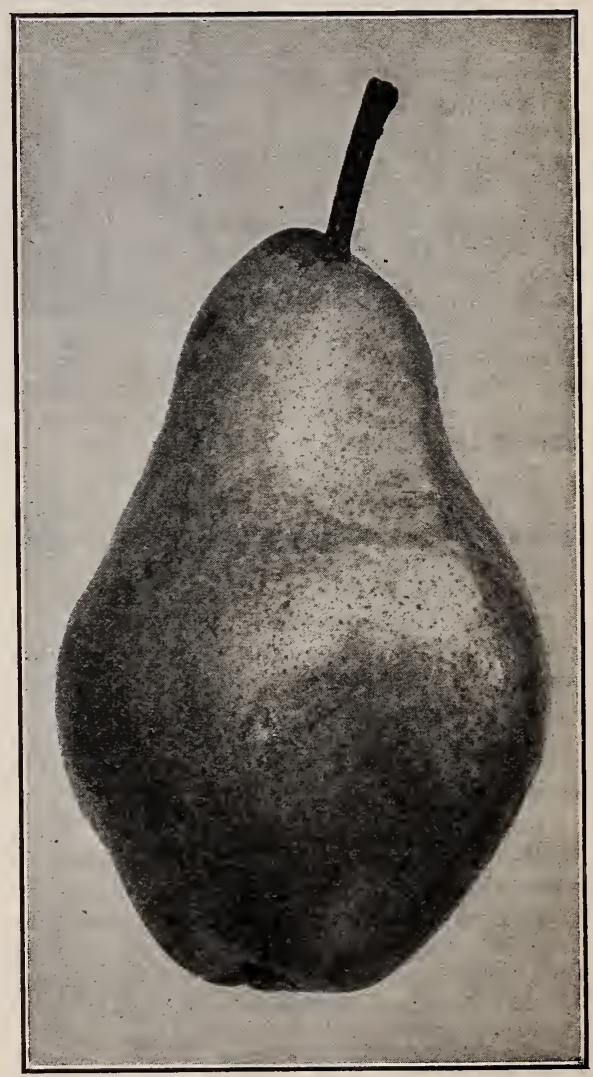

Bartlett-Most Profitable Market Pear 


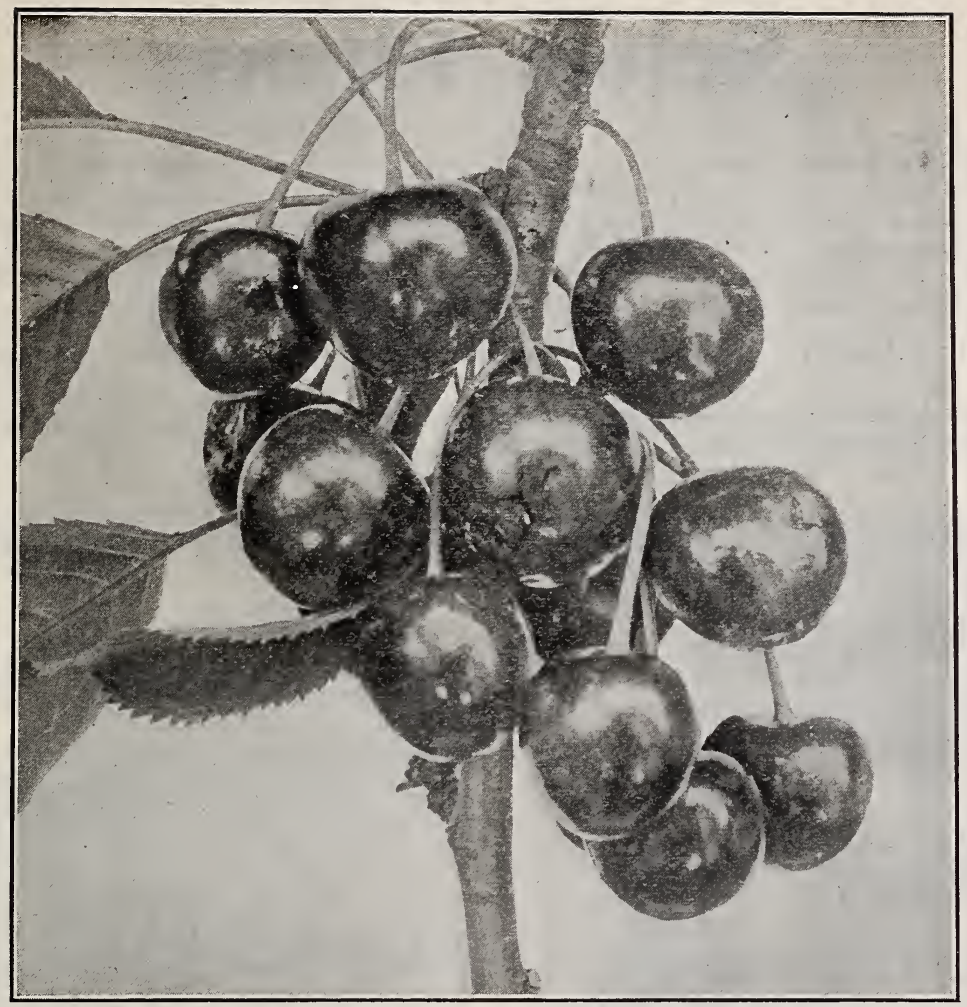

Large Montmorency-Most Profitable Hardy Market Cherry

\section{Select Cherries}

Cherries succeed well in dry soils. Every Fruit Garden should have one or more cherry trees. I do not believe there is a single town in the United States where the market has been well supplied with the delicious fruit. The demand has always been greater than the supply. Farmers and fruit growers need not fear to plant this fruit largely.

Prices of first-class Cherry trees of the following varieties, Montmorency, Early Richmond and Dyehouse, 2 to 3 years, 4 to 5 feet high, 25c. each, $\$ 2.50$ per dozen, $\$ 20$ per 100 . Extra size, 5 to 6 feet high, $30 \mathrm{c}$. each, \$3.50 per dozen, \$25 per 100 .

Large Montmorency-Most popular of all hardy cherries, for market and home use. This cherry is planted more largely in orchards than any other kind. It is of a large size and light red "in color. Stems rather short. The tree is very hardy and a vigorous grower; bears fruit soon after planted. (See cut on front cover.)

Early Richmond-An early red acis cherry; very valuable for cooking early in the season. Tree a free grower, hardy and healthy.

Dyehouse-A very early and sure bearer; ripens a week before Early Richmond. Very productive.
Prices of first-class Cherry trees of the following varieties, Black Tartarian, Napoleon and Windsor, 2 to 3 years, 5 to 6 feet high, 35c. each; $\$ 4$ per dozen, $\$ 30$ per 100. Extra size, 6 to 7 feet high, $40 \mathrm{c}$. each, $\$ 4.50$ per dozen, \$35 per 100 .

Black Tartarian-Very large, purplish black. Tree a remarkably vigorous, erect and beautiful grower. One of the most popular varieties.

Napoleon-A magnificent cherry of the largest size; pale yellow, with a bright re.l cheek. Tree a vigorous, erect grower; ripens late; valuable for canning.

Windsor-Fruit large; liver color. Ripens about one week after Black Tartarian. Flesh remarkably firm and of a fine quality. Tree hardy and very prolific. Very valuable variety for market or family use.

(See cut on front cover.) 


\section{Select Plums}

The Plum is one of our most healthful and useful fruits, and when carefully and judiciously cultivated, one of the most profitable also. The curculio is its chief enemy, but if it is combated with skill its ravages can be reduced to a minimum. As soon as the blossoms are fallen, spread two sheets under a tree, and with a hammer strike a hard blow on the stub of a limb sawed off for that purpose. Kill the insects which drop on the sheets. Collect all the fallen fruit and feed to swine, or burn. Keep this up every morning before sunrise for two weeks, and you will get a good crop of fruit. ities.

The new Japan Plums are enormously productive and combine many desirable qual-

Prices of Plum trees, first class, 2 to 3 years, 5 to 6 feet high, 30c. each, $\$ 3$ per dozen, $\$ 20$ per 100. Extra size, 35c. each, $\$ 3.50$ per dozen, \$25 per 100 .

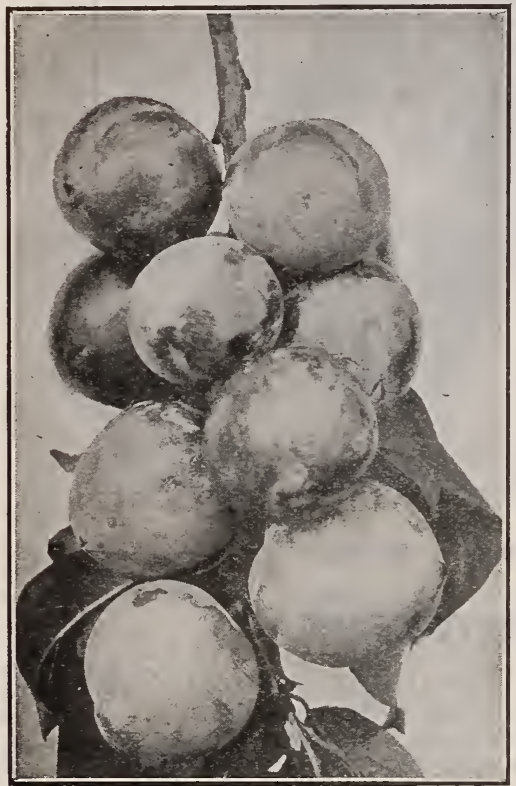

Burbank-Most Profitable for Market.

Burbank-Best and most profitable among growers for market; ripens ten to fourteen days after Abundance. Tree hardy, sprawling, vigorous grower, unequalled in productiveness; bears young. Fruit large, excellent quality; cherry red with lilac bloom.

Bradshaw-A very large and fine early plum; dark violet red. Tree erect and vigorous; valuable for market.

Fellemberg (French or Italian Prune) -A fine late purple plum; fine for $\mathrm{A}^{-} y i n g$. Tree a free grower and very productive.

German Prune-Medium; oval; blue, juicy, rich. Tree vigorous and very productive.

Abundance (Botan)-One of the oldest and best known Japanese varieties; hardy and productive. Fruit large, lemon yellow, with heavy bloom; good quality.
Grand Duke-A valuable late plum; as large as the Bradshaw, and entirely free from rot. One of the best late plums for market.

Imperial Gage-Rather large; oval; greenish; flesh juicy, rich and delicious; parts from the stone. One of the best plums.

Lombard-Medium size; oval; violet red; flesh yellow. Tree a vigorous grower, peculiarly adapted to light soils; very hardy.

Red June-Recommended as "by all odds the best Japanese Plum, ripening a week before Abundance." One of the vigorous, upright growers; productive; fair size, vermilion red; pleasant quality.

Yellow Egg-A very large and beautiful egg-shaped yellow plum; a little coarse, but excellent for cooking; very productive.

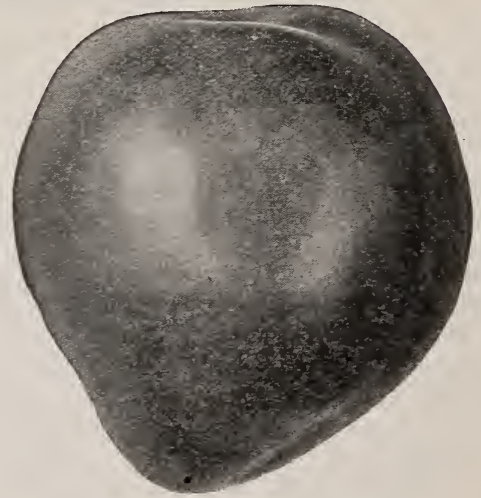

\section{Wickson-An Excellent Shipper.}

Wickson-Fruit remarkably handsome, very large, long, heart-shaped, color deep maroon red covered with white bloom; flesh firm and meaty, yellow, rich and aromatic; cling; pit small. Tree an upright, vigorous grower. Excellent keeper and shipper. Is being planted largely for market. 


\section{Select Peaches}

To secure healthy, vigorous and fruitful trees and fine fruit, the following points must be well attended to in peach culture: 1st. Keep the ground clean and mellow around the trees, and give it an occasional dressing of wood ashes. $2 d$. Keep the heads low - the trunks ought not to exceed three feet in height. 3d. Attend regularly every spring to pruning and shortening the shoots of the previous year's growth. This keeps the head round, full, and well furnished with bearing wood. Cut weak shoots back about one-half, and strong ones one-third, but see that you have a sufficient supply of fruit buds. Sickly and superfluous shoots should be cut clean out.

NOTE.-In planting peaches, it is of the highest importance to cut back the trees severely. The stem should be reduced about one-third and the side branches cut back to one bud. This lessens the demand upon the roots, and enables the remaining buds to push more vigorously. Most failures in newly-planted orchards may be ascribed to a non-observance of these directions.

Price of Peach trees, first class, 3 to 4 feet high, well branched, 15c. each, $\$ 1.50$ per dozen, \$10 per 100. Extra size, 18c. each, \$1.80 per dozen, \$12 per 100.

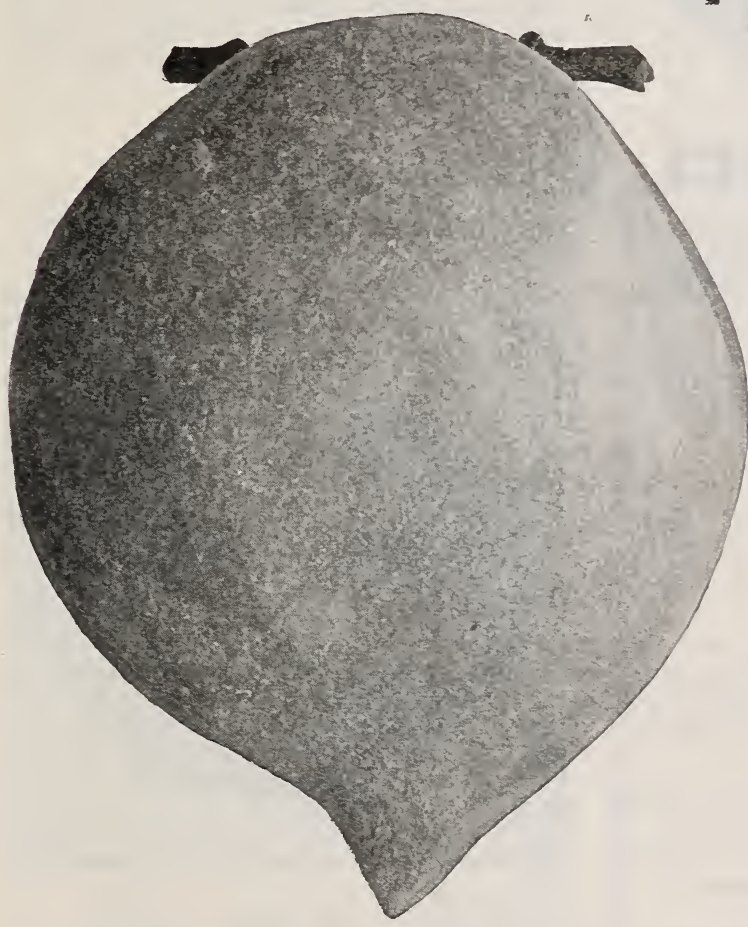

Elberta, One of the Best Orchard Varieties

Champion - Early; l a r g e, handsome, creamy white with red cheek. Sweet, rich, juicy. Free stone; hardy and produetive.

Crawford's Early-A magnificent, large, yellow peach, of good quality. Tree exceedingly vigorous; its size, beauty and productiveness makes it one of the most popular varieties.

Crawford's Late-A superb yellow peach; very large, productive and good; ripens here about the last of the peach season.

Crosby-Fruit medium, roundish, bright orange yellow; good in quality. Ripens between Crawford's Early and Late.

Golden Beauty-A large, yellow peach with red cheek. Flesh yellow, firm and excellent flavor. Fruit uniformly large and showy. Tree good bearer.

Mountain Rose-Large ; flesh white, juicy, very good; free stone. Very productive. An excellent early market variety.

Sineed-Earliest of all peaches. White; excellent quality; very productive; does not rot.

Elberta-Large, yellow, with red cheek; flesh yellow, firm, juicy. Exceedingly prolific, sure bearer and hardy. The leading market variety.

Carman-Large, resembles Elberta in shape; color, creamy white or pale yellow with deep blush; skin very tough, flesh tender, fine flavor and quite juicy.

Snow Cling-Very large; flesh white; juicy and melting. Good keeper and shipper.

Alexander-Medium to large size; rich red, juicy and sweet. Tree vigorous and productive; one of the largest and best of the extra early varieties; valuable for market.

Look! Grapes at a bargain! One-third off regular prices. One car load must be sold. We offer 1 Agawam, Red; 1 Campbell's Early, Black; 3 Concord, Black; 2 Diamond, White; 3 Niagara, White; 2 Worden, Black; 12 Two Years Old, First Class Grape Vines for 73 cents, regular price, $\$ 1.06$. 


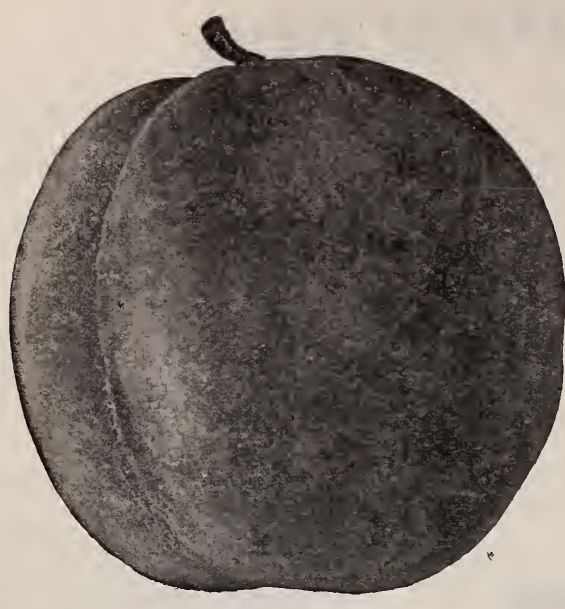

Krumme! Late.

Krummel Late, New-Without doubt the most profitable late peach. A fine, large, handsome, golden yellow with bright red cheek. Free stone; very juicy. Ripens in October. Keeps longer than any other peach. Fine flavor; best quality. Price of Krummel Late Peach trees, large size, 25c. each, $\$ 2.50$ per dozen. Medium-size, 20c. each, $\$ 2.25$ per dozen.

Trees are Extra Fine.

Ohiø, May 3, Igo5.

Dear Sir:-Trees and plants were nice and all right and many thanks for the fine lot of plants. The Pear trees are extra fine looking, so you know I am well pleased. ANNA JANSON.

Yellow St. John-A superfine early yellow freestone, nearly as large as Crawford, as finely colored and of even better flavor. Its round, showy fruits always attract attention and sell well. A fine dessert Peach. The tree bears while still small, and abundantly afterward.

\section{Select Quinces}

Price of Quince trees, first class, 3 to 4 feet high, $40 \mathrm{c}$. each, $\$ 4.50$ per dozen.

Apple, or Orange-Large; roundish, with a short neck; of a bright golden yellow color. Tree has rather slender shoots and oval leaves; very productive. This is the variety most extensively cultivated for the fruit.

Champion-A prolific and constant bearer, fruit averaging larger than the orange, more oval in shape, quality equally fine, and a long keeper; bears extremely young. Ripens late.

Meech-A vigorous grower and immensely productive. The fruit is large, lively orange yellow, of great beauty and delightful fragrance; its cooking qualities are unsurpassed.

Rae (Rae's Mammoth) -A very large and fine variety of the Orange Quince. A strong grower and productive. We consider this the best of all the quinces.

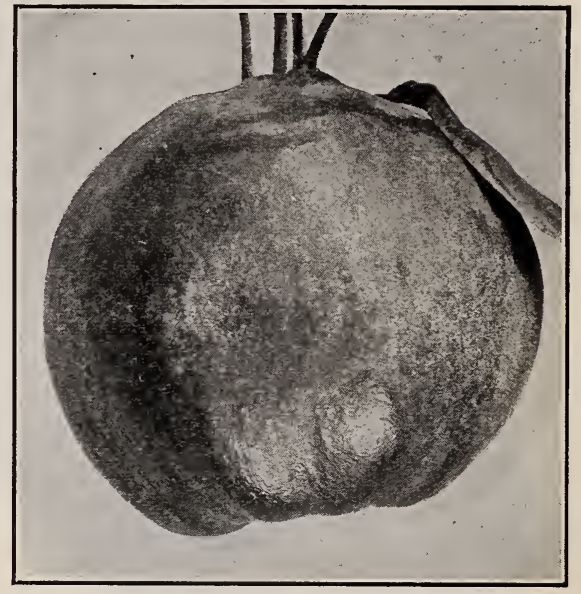

Orange.

\section{PER CENT. SAVED}

This is the difference between wholesale and retail prices of trees and plants. We are selling trees and plants to planters at nearly wholesale prices. How can we do this? We can do it for the simple reason that we do not have to pay salaries to tree agents and tree peddlers to canvass the entire country. We have no agents. Our catalogue is our only agent. Those nurserymen who sell through salesmen spend half the money they get for the sale of trees in paying agents and agents' expenses. 


\section{HARDY ROSES}

In order to supply the increasing demand for Roses, we have enlarged our facilities and are now propagating plants on a more extensive scale than ever.

We endeavor in our Catalogue to present the merits of each variety fairly and faithfully, being cautious not to overpraise, preferring to say too little rather than too much. Recognizing the importance of robust, healthy habit, hardiness and freedom of bloom, combined with beauty of flower, we are propagating varieties possessing these characteristics, and most strongly and confidently recommend such kinds for general planting. Our immense stock and great variety of hardy Roses enables us to furnish our customers a large assortment to choose from. Our Roses are all strong, field-grown, two years old plants. They will bloom this season.

\section{Points in Rose Culture}

The Rose delights in an open, airy situation, unshaded by trees or buildings. All the types are partial to clay loam, but will do well in any ordinary soil if enriched with wellrotted barnyard manure. Dig the soil up thoroughly to the depth of twelve or fifteen inches, as rose roots penetrate deep when they have a chance. Do not raise the surface of Rose beds above the surrounding surface. They suffer less from drought when left level with the turf. After the plants have been set out, keep the soil loose to the depth of an inch or two, by frequent stirrings. An occasional soaking with weak manure water is a great help to Roses of all sorts.

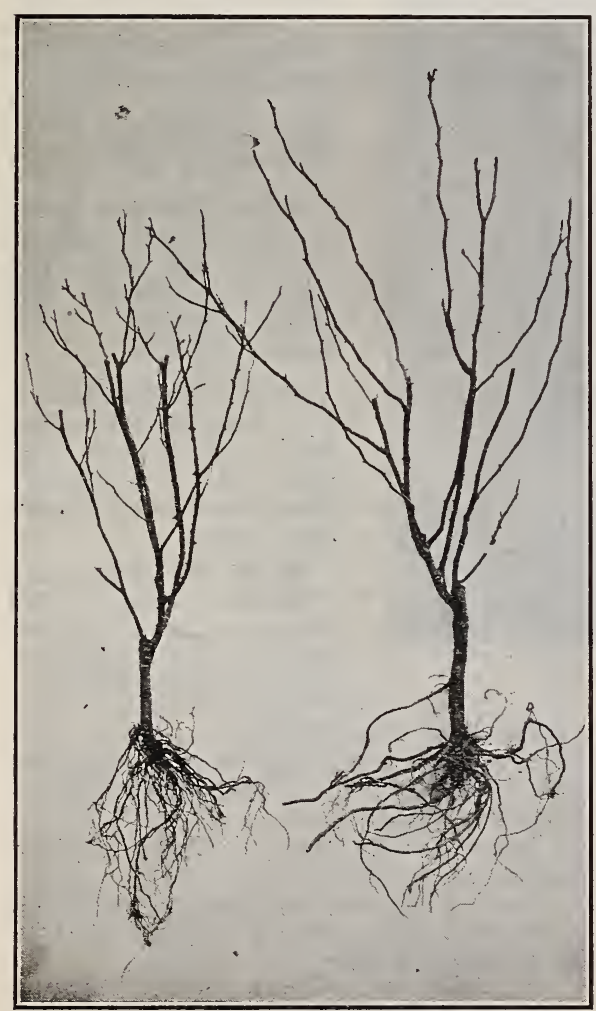

Photograph of Our Two Years Old FIELD-GROWN ROSES

The Kind We Send Out

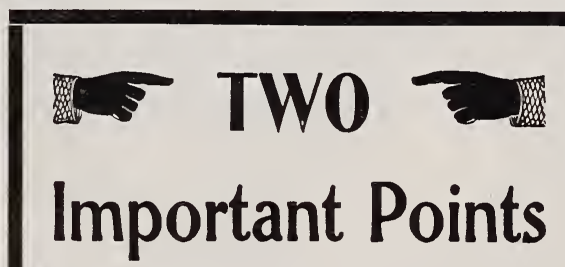

Wood's

Rose Stock

Is All

Two Years'

Field-Grown

With Extra

Fine Roots

We remind you of these two points, as some firms offer Roses at lower prices, but do not tell you the size of the plants. When you buy WOOD's ROSES you know just what you are getting. 


\section{Hardy

Hybrid Perpetual Roses are the most valuable for outdoor planting wherever a permanent bed is desired. They are perfectly hardy and will stand our most severe winters, and when once established they improve in beauty every year. They will do well almost anywhere, but delight in a deep, rich soil. A mulching of straw or leaves will greatly benefit them if applied in the fall and allowed to remain until spring.

Prices of strong, two years old, field-grown Roses (see cut), 20c. each, 6 for $\$ 1.15,12$ for $\$ 2.25$.

Roses sent by mail or express prepaid, 25c. each, 6 for $\$ 1.30$, 12 for $\$ 2.50$.

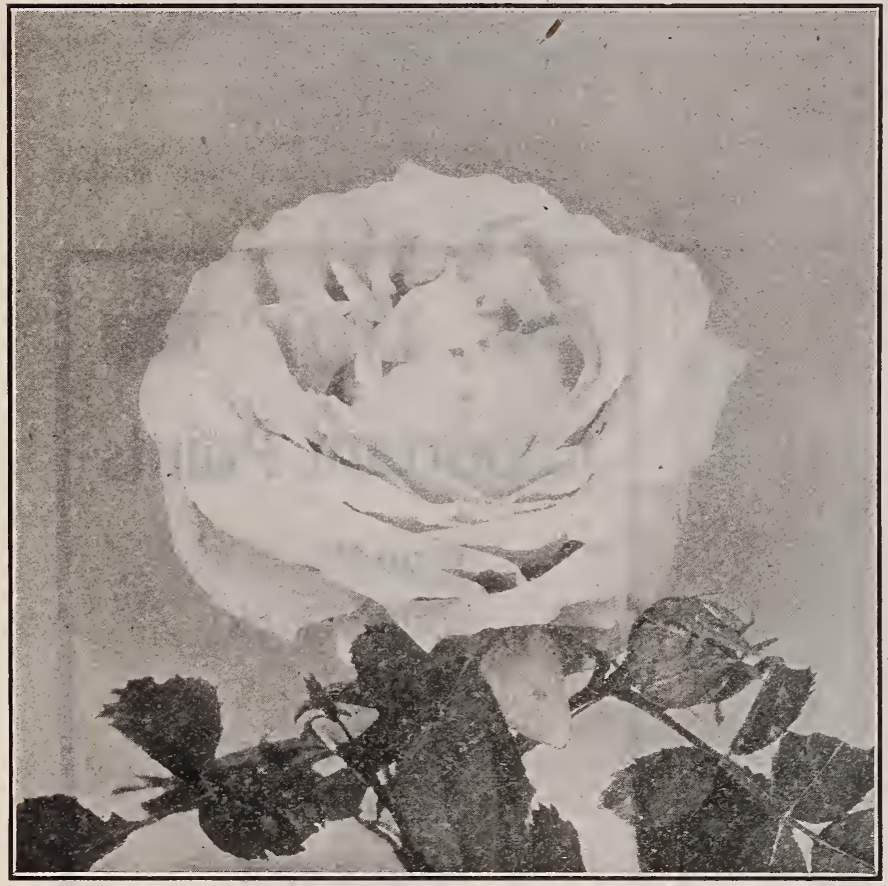

Frau Karl Druschki.

Clio-A Rose of perfect form and finish, with broad, thick petals, high, full center, beautiful from pointed bud to fully opened flower. The color is a delicate satiny blush, with slightly deeper center. The plant is strong and blooms freely, displaying its great flowers boldly on good stems against large, rich leaves.

(See cut on back cover.)

Alfred Colomb-A superb brilliant crimson rose, of very large, full form, extremely fragrant; blooms freely and grows well.

Anne de Diesbach-. Very large and fragrant flowers of a rich carmine color. A notably hardy and superior garden Rose.

Baron de Bonstetten -Large, deep full flowers of dark erimsonmaroon. A splendid, highly scented flower.

Frau Karl Druschki or (Snow Queen)Now offered for the first time in this country. This exquisite new rose is the only absolutely pure white rose ever introduced. It is of German origin. It is a cross between the Mad. Caroline Testout and the grand old white rose Merveille de Lyon. It possesses the free-blooming qualities of the former and the robust growth of the latter. It is perfectly hardy everywhere and a most vigorous grower, throwing up enormous shoots which are covered with snowwhite blossoms.

Prices of Frau Karl Druschki, two year old, field-grown plants, 25c. each, 6 for $\$ 1.30,12$ for $\$ 2.50$. If by mail add 5c. to each plant.

(See above cut.)

Baroness Rothschild-A grand pink Rose, of full cupped form and exquisite pale pink color. Short-jointed, very hardy, late-blooming, scentless.

Duke of Edinburgh-Brilliant erimsonscarlet, shaded with maroon.

Crested Moss-Deep pink colored buds, surrounded with a mossy fringe and crest. Very beautiful rose.

Coquette des Alpes-A free-blooming Rose, of medium size; white, tinged with pale rose. Exceedingly dainty and attractive.

General Washington-One of the freest blooming Roses of this class. The flower is perfectly double, of a beautiful, soft scarlet shade, sometimes shading in glow• ing crimson. 
John Hopper-A fine and free-blooming old sort, with large, full, handsome flowers of fresh, bright rose.

General Jacqueminot -The famous bud and forcing Rose, quite as well adapted for garden culture by its fine, hardy habit. Its unusually fragrant flowers are a brilliant glowing crimson, not very full, but large and extremely effective.

Coquette des Blanches -A finely formed white rose, with shell-shaped petals evenly and daintily arranged. Of free growth and bloom, with fine dark leaves and almost thornless stems. Newly expanded flowers and sometimes tinted with blush.

Mabel Morrison - A grand white rose, similar to Baroness Rothschild in all save color.

(See cut on back cover.)

Madame Plantier-Pure white, above medium size, full. Produced in great abundance early in the season. One of the best white roses for hedges and for massing in groups.

Marshall P. Wilder-One of the best dark red Hybrid Perpetuals; the flowers are large and perfect in form, on good length of stems, making them very desirable for cut flowers; color bright cherry red, changing to crimson.

(See cut on back cover.)

Cleveland, $\mathrm{O}$.

Dear Sir:-Your Roses are the largest and best I have ever bought. I never saw Roses having such roots and I was surprised to see them all bloom in June. The LaFrance bloomed all summer. MRS. REUBEN WALKER.

Marie Van Houtte-Plant Marie Van Houtte if you wish a rose that will bloom continually and furnish large, well shaped, sweet scented bloom. It succeeds any. where and in any soil; an exceedingly strong, vigorous grower. Its color is creamy white, with the outer petals outlined bright rose; occasionally the entire flower is suffused with light pink.

Earl of Dufferin-Rich crimson-maroon, with dark and velvety shadings. The flowers are large, full, globe-shaped, thickpetaled and very fragrant. Grows well and blooms freely, with many handsome buds in autumn. One of the finest dark Roses.

\section{American Beauty.}

American Beauty-One of the largest and most beautiful of the hardy roses. Flowers very large and double, and delightfully fragrant. Color a rich rosy crimson. Plant a strong grower and continuous bloomer. It will make a much stronger growth if not allowed to bloom the first summer. Pinch off the larger portion of the buds-better, all of them. This will not be necessary the second season, as the plant will then be strong enough to make both growth and bloom. (See cut.)

Paul Neyron-The largest Rose in cultivation, sometimes called the Peony Rose; color bright, fresh cerise-red. The plant makes a strong, healthy growth, and has clean, glossy foliage; blooms almost without intermission from June until late October.

Marchioness of Londonderry-Ivory white flowers of great size and substance, perfectly formed, on stout stems; highly perfumed; free blooming.

Jubilee-A notable Rose of recent introduction, that ranks among the best dark sorts. Deep, flashing crimson, with shadings of velvety maroon; very large, and quite fragrant. Of compact, bushy growth, with good, dark foliage and long flowerstems.

Magna Charta-A hybrid China that is very fine early in the season; bright rose, large and full. 
Margaret Dickson-A large and handsome white Rose, of extra-vigorous growth. Its large petals are thick and shell-shaped, of good substance, tinted.

Prince Camille de Rohan-A velvety, blackish crimson rose, of deep, distinct shade; large, full, very handsome.

(See cut on back cover.)

Persian Yellow-Bright yellow, small, nearly full. It is desirable to grow more than one plant, and by pruning one plant one year, and the other the next year, annual erops of flowers may be had.

(See cut on back cover.)

Mrs. J. H. Laing-An exceptionally handsome and free-blooming rose, of vigorous growth and fine habit. The color is a soft delicate shade of pink; the flower is large and well formed, very fragrant and produced on good stems. A variety of special value, as it blooms continuously in the open ground, and is also excellent for forcing, the buds selling at high prices.

Mrs. R. G. Sharman-Crawford-Grandly formed flowers of a warm, delicate shade of pink; pale flesh on the outer petals, deep rose in the center. The large, thick petals are finely imbricated; the flowers are produced on splendid stems. The plant makes a vigorous growth and blooms from early summer until autumn.

\section{Fine Condition.}

Kansas, Mar. 28, 1905. Dear Sir:- The Rambler and Red Cross came in fine condition. Shall order again.

Yours truly,

M. J. R. TREAT.

Ulrich Brunner-A Rose of beautiful form and finish, very striking from its color of brilliant cherry-crimson. The bush is vigorous, blooming continually in the open air, and displaying its superb, glowing flowers on good stems.

Soleil D'or-New yellow Rose, hardy enough to withstand the winters of our Northern states. The buds are a marvelous shade of rich chrome yellow with just a tinting of coppery rose in the center. The fully expanded flower is beautiful in its blendings of orange yellow, reddish gold and nasturtium red, forming a coloring impossible to satisfactorily describe. This grand seedling has been shown at all the large Rose exhibitions in Europe and has received the highest awards.

Ia France-Delicate silvery Rose, shaded with cerise pink, often silvery pink, with peach shading, very large, double and of superb form. It flowers continually throughout the season. None can surpass the delicacy of its coloring.

(See cut on back cover.)

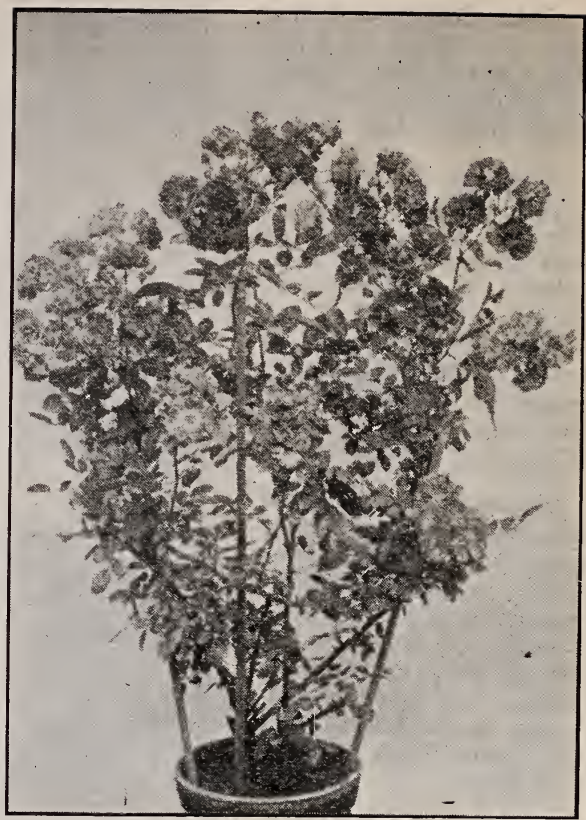

Baby Rambler.

\section{The Everblooming Dwari Rose}

The greatest bedding and house rose in existence. It blooms every day of the year in the house. Out of doors from May until November.

The plants are very vigorous, grow to a height of about 24 inches. The foliage is dark, glossy, profuse and remarkably free from insects and fungus.

The flowers are borne in clusters, 20,30 and 40 flowers to a cluster. They are in every way just like those of the Climbing Crimson Rambler and are produced perpetually. We have closely watched this new Rose for the past two years and they have never been without flowers from that time till the present day. We had a large bed in our grounds at Brighton, N. Y., and there the plants were constantly in bloom until November-even in the hottest weather. This is a remarkable record. We have grown hundreds of varieties of Roses, but have never met one that possesses all these remarkable qualities combined.

It is certainly a fine Rose for indoors, and for bedding and massing in private grounds, parks, cemeteries, \&c.

(See cut on back cover.)

Prices of Baby Rambler 2 years old, strong, field-grown plants, 50c. each, 3 for $\$ 1.35,6$ for $\$ 2.50,12$ for $\$ 4.75$. 


\section{Hardy Climbing Roses}

Prices of all varieties of Climbing Roses, strong, 2 years old, field-grown plants, 25c. each, 6 for $\$ 1.25$, 12 for $\$ 2.40$. If sent by mail add 5c. to each plant.

Crimson Rambler-Without doubt the greatest acquisition of a lifetime. The sale for a single season reaches enormous numbers, yet the supply is scarcely equal to the demand. It is perfectly hardy; has never killed back in the slightest degree on our home place, where the mercury frequently registers twenty degrees below zero. Very vigorous in growth, often making shoots 10 to 12 feet long in one season, with canes one-half inch in diameter. May be grown in any position, pegged down to the ground in beds, trained tc porch pillars, the side of a building or on trellises. Flowers glowing crimson, produced in large panicles, many measuring 9 in. long and 7 in. across, entirely covering the plant. (See cut.)

Dorothy Perkins-This is a splendid, new shell-pink Climbing Rose. It attracted much attention at the Pan-American Exposition, where a bed of fourteen-months-old produced a show of bloom unequalled by any other variety, unless. it was the famous Crimson Rambler. This new rose is of the same strong habit of growth as Crimson Rambler, and the flowers are borne in clusters of 30 or 40 and sometimes even 50 to 60 . The flowers are large for a rose of this class, very double, sweetly scented and of a beautiful shell-pink color. Absolutely hardy. The individual flower is larger than the Crimson Rambler.

Baltimore Belle-Very double blush white, in large clusters, completely enveloping the whole plant with bloom.

Prairie Queen-An old standard variety, and one that will alwavs be popular. No collection of hardy climbing roses is complete without it. Bright rosy red, large, compact and globular flower.

Seven Sisters-A splendid rose, blooming in clusters; crimson, changing all shades to white.

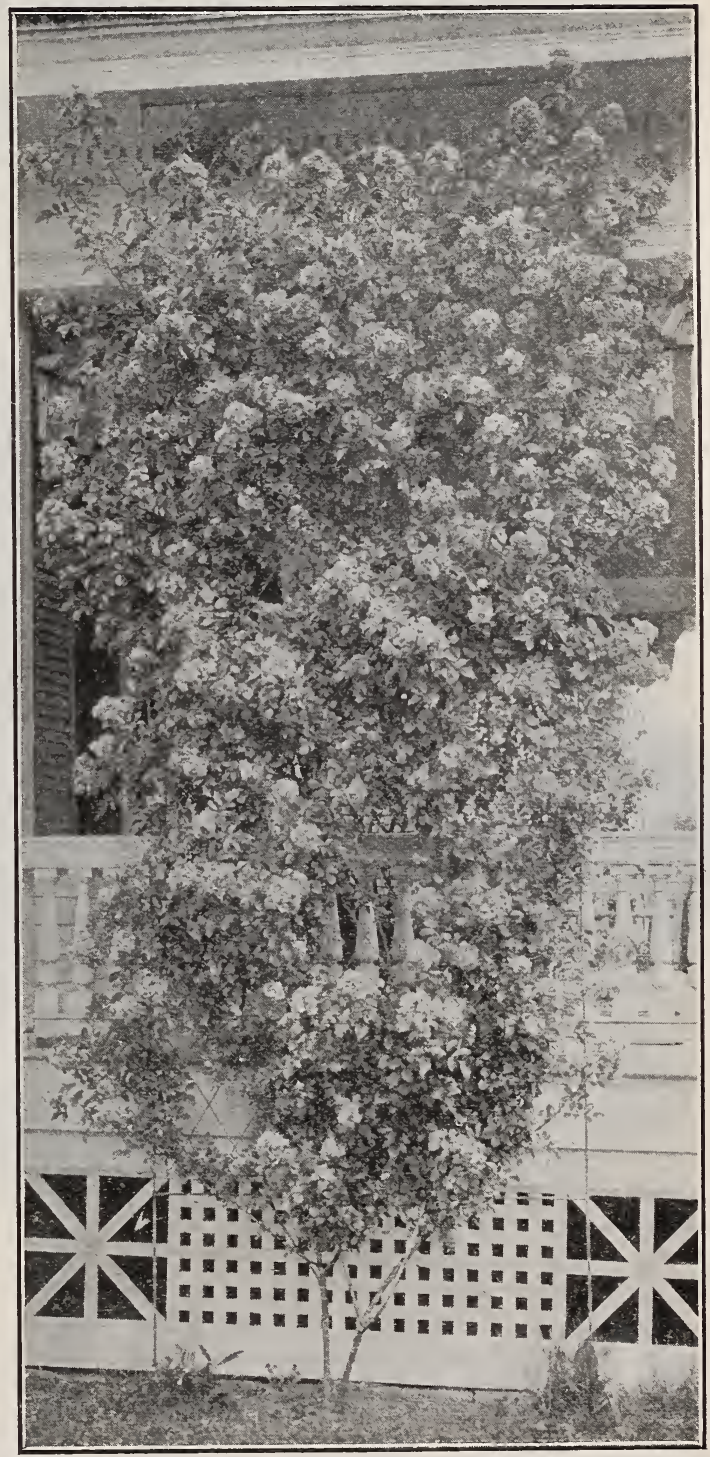

Crimson Rambler.

\section{No. 18-STATE OF NEW YORK-DEPARTMENT OF AGRICULTURE}

\section{Certificate of Inspection of Nursery Stock}

This is to Certify that the stock in the Nursery of Allen L. Wood, of Rochester, County of Monroe, State of New York, was duly examined in compliance with the provisions of Chapter 519 , of the laws of 1902 , and it was found to be apparently free in all respects from any contagions or infectious plant disease or diseases, or the San Jose scale, or other dangerously injurious insect pest or pests.

Dated, Albany, N. Y., Sept. I, I905.

C. A. WIE'TING, Commissioner of Agriculture. 


\section{Choice Strawberry Plants}

We are greatly pleased to offer our customers this year some new strawberries of great merit. An improvement over many kinds being offered by other dealers and growers. We find it pays to grow only the Best for big returns and good results.

You must grow good varieties to succeed. It is absolutely necessary to do it or you fail, no matter how good your ground is.. Get the best, it costs no more. We have built up a good business by sending out the best stock, true to name, that has made our cus. tomers money and friends for us.

\section{Strawberries by Mail}

At dozen rates we prepay postage, at hundred rates add 20c. per 100.

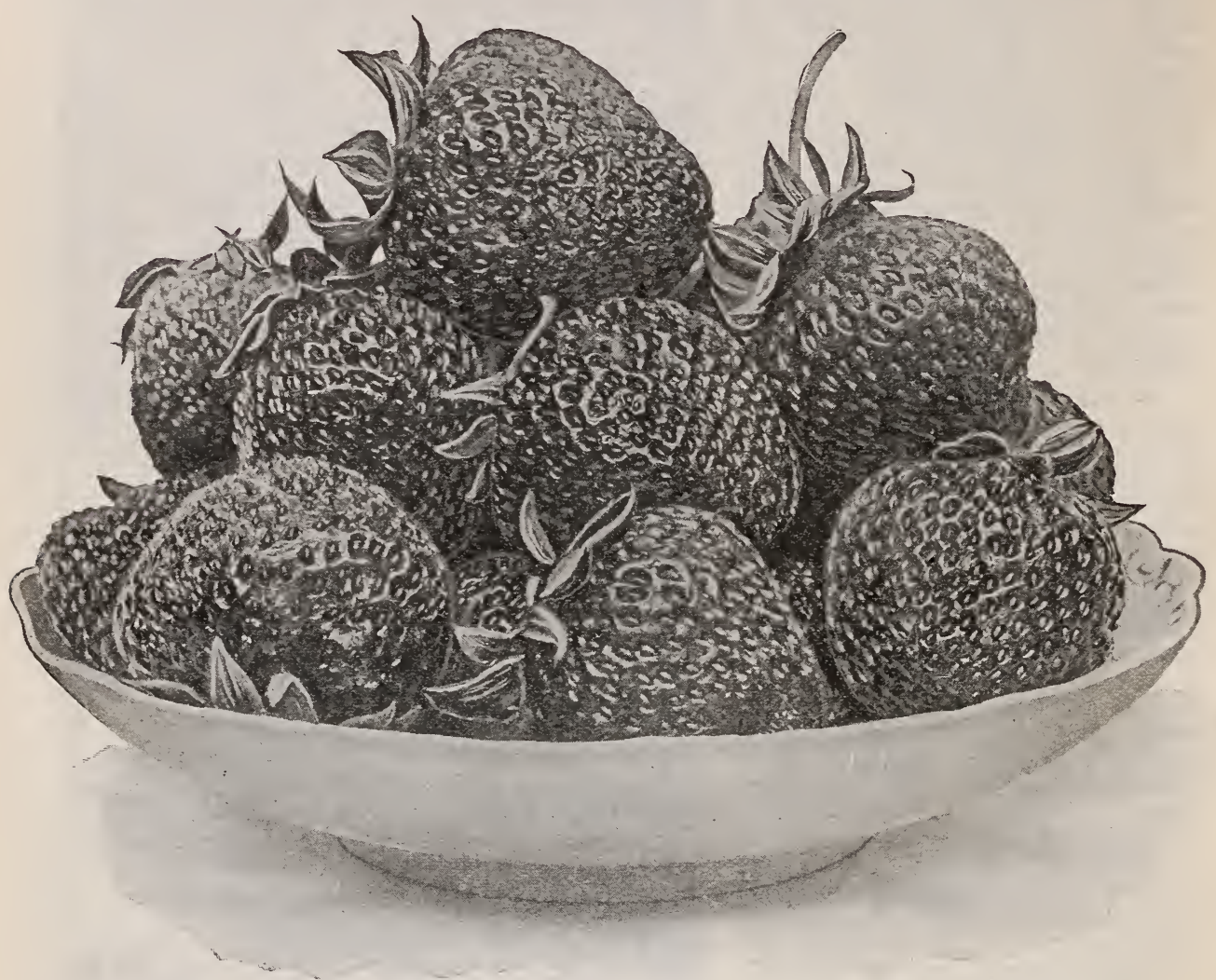

Climax.

Climax, Per.-This new berry originated in Maryland and has become very popular. The foliage is a beautiful light green that can be distinguished from other varieties as far as you can see the patch. The plants are strong and healthy; no rust. Season of ripening, early to medium. Size of fruit, rather above medium; productiveness simply immense. I think there is no variety that has ever been offered that has a greater record for immense productiveness than the Climax. I sold all the plants I had last spring long before the shipping season was over and refused orders for a great many thousands of plants. Our stock this season is limited and I advise my customers to order early. Price, 30c per dozen, 65c. per 100, \$4 per 1000.

Stevens' Late Champion, Per.-A late money-making variety, yielding enormous crops of large, beautiful and good berries that ship well very late in the seasonafter almost all other varieties have ripened and disappeared. The plant is an exceptionally healthy and good grower. Anyone who wants a good, late kind should plant Stevens' Late Champion, as it is properly named. Price, 35c. per dozen, 75c. per 100, \$5 per 1000 . 


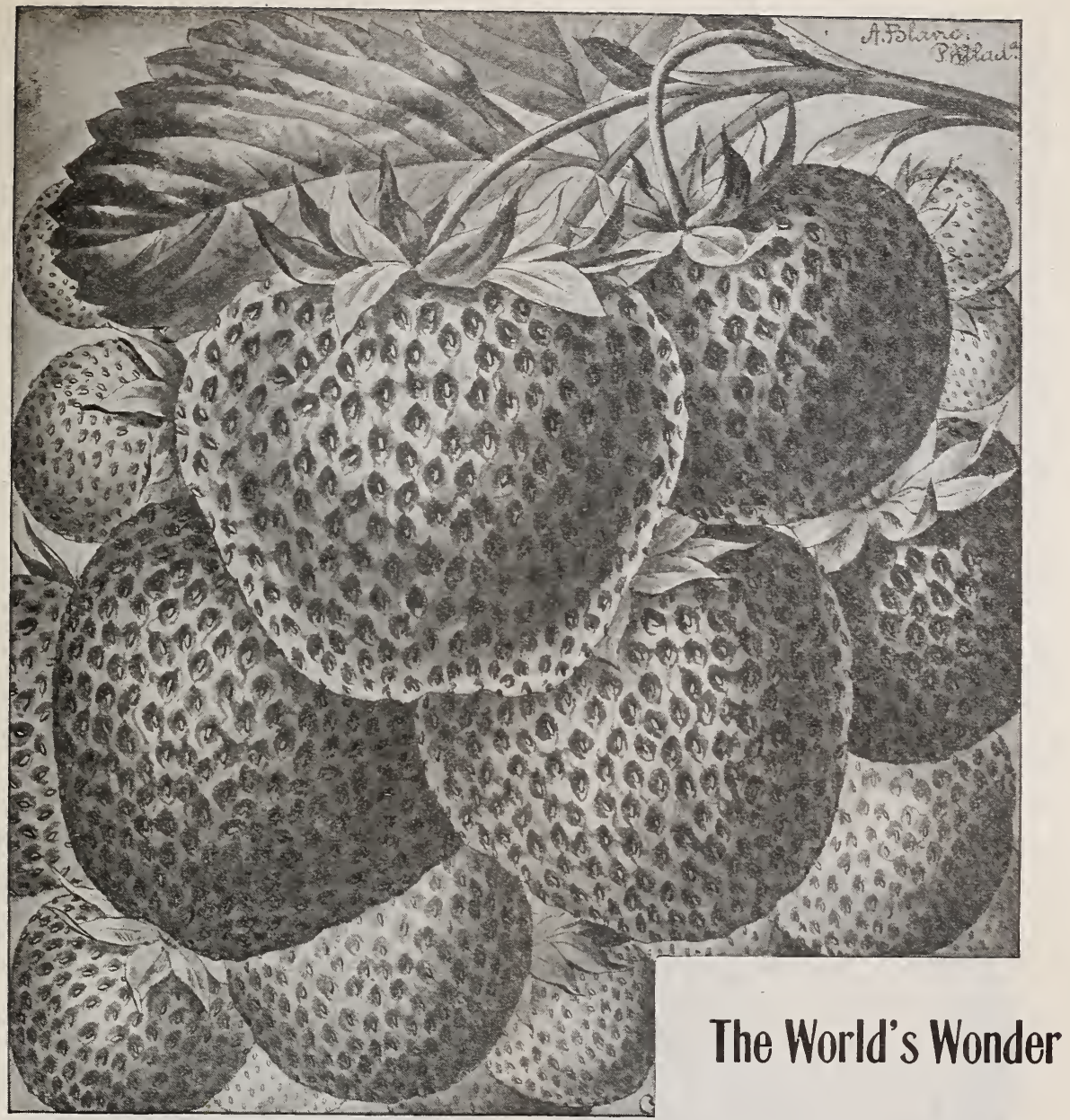

World's Wonder-This great strawberry originated with Mr. R. G. Parsons, of Maryland, one of the largest strawberry growers in that state. I have a written contract with Mr. Parsons for all the plants of this wonderful new berry.

The World's Wonder is as productive as the Haverland, but twice as large. Fruit is a bright red in color and does not turn dark after being picked. Uniform in shape, large size, good keeper and shipping berry. Ripens early and brings extra fancy price on market. Vines are strong, thrifty and rapid in growth. Will produce a large erop on either high or low land. The fruit is so firm and its keeping qualities are so excellent that it does not need to be picked oftener than once in three days.

It is a variety that will please you and you can make lots of money by planting World's Wonder, but you will have to speak quick if you want these plants as they will go like hot cakes. We are only going to sell 50,000 plants and the rest we are going to plant out. We know we can make more money by planting them out for fruit. I am confident you will be surprised and pleased with the variety when you see it fruiting on your place.

Prices on World's Wonder Strawberry, 50c. per dozen, $\$ 1.50$ per 100; $\$ 6$ per 500, $\$ 10$ per 1000. (See cut on front cover.)

Dear Sir:-The World's Wonder is a beautiful berry Parsonsburg, Md., July I2, I905. all strawberries in this section.

Dear Sir:- Boston, Mass., June 2, 1905. - ish you had plenty of tind sales for the crate of fancy berries, World's Wonder at 20 cents per quart. We Fish you had plenty of them to send this year and hope you will have the berry well introduced, so that
our market can have some of them next year. 
Oaks Early, New-Five years ago last May Mr. Wm. T. Tull, while hoeing corn, found a strawberry by an oak stump which attracted his attention on account of its unusual growth. The next spring he dug up all the new plants and planted them in his garden. The following year they ripened an unusually large crop of choice berries at the same time with the Michaels Early and Hoffman, but it is a superior, stronger grower and three times as productive. In the spring of $1905 \mathrm{Mr}$. Tull had six acres of Oaks Early in cultivation. These berries have proved to be a gold mine to him as he has cleared nearly double the amount of money he paid for his farm, three years ago. For the past three years strawberry growers have offered Mr. Tull fancy prices for some of his plants but he refused to sell any of them. In the spring of 1905, ten of the largest strawberry growers combined and made him an extraordinary offer for the six acres and got the plants. We heard of the deal and got 1000 plants from one of the growers, and they have made a wonderful growth, and we will offer a few plants for the first time.

Price of Oaks Early, 50c. per dozen, $\$ 1.50$ per 100.

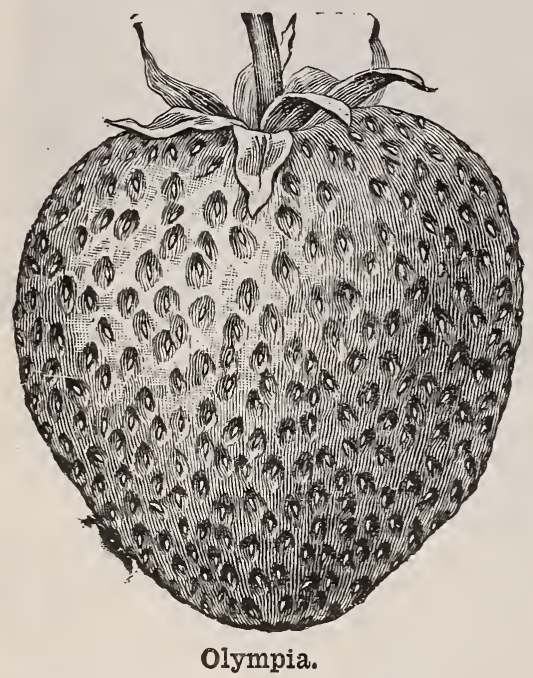

Olympia-New, Per.-Originated in California. Will endure more drought than any other strawberry we have ever grown. It is being planted very largely in California. The root of the Olympia penetrates into the ground deeper than any other strawberry we have ever grown. Strong, robust grower; very productive. Fruit medium to very large. Fruit stalks exceedingly stout. Ripens midseason. Will do well on light, dry soil. Price, 35c per dozen, $\$ 1.00$ per 100 .

Armstrong-Per.-(This berry is being sent out under two other names, Corsican and Morgan's Favorite.) This strawberry was brought over from Germany by Mr. Armstrong and was named after him. It is very large and very productive on heavy soil and it produces very large berries. Its foliage is exceedingly vigorous and leathery. The fruit brings from three to five cents more per quart on the market than any other variety. Price, 30c. per dozen, 65 c per $100, \$ 4.00$ par 1000 .

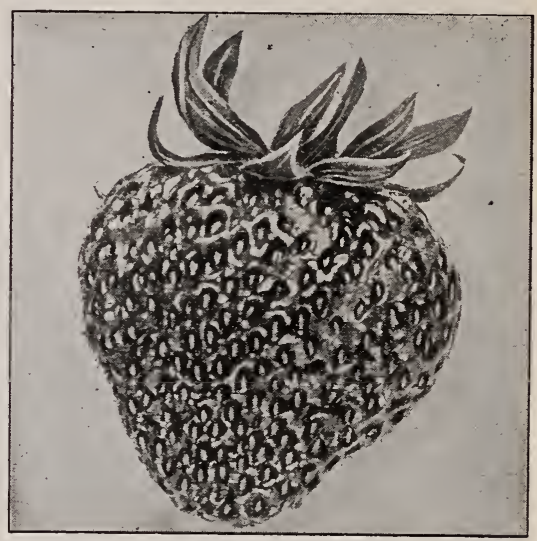

Senator Dunlap.

Senator Dunlap-Season early to medium. Popular market sort. It withstands all conditions of weather beyond the average. Very productive, dark red through and through. If you want a variety that will give you good returns do not fail to plant the Senator Dunlap. Price, 25c. per dozen, 50c. per 100, \$3 per 1000.

Beder Wood, Per.-Large, roundish, conical, bright scarlet, moderately firm, fair quality. A very heavy bearer. This berry, all things considered, is one of the best early berries we have ever fruited for market. Price, 25c. per dozen, 50c. per 100, $\$ 3$ per 1000 .

Brandywine, Per.-A very late and firm berry; a good shipper and canner, in fact, a good all round berry. This strawberry is being largely planted and much liked. The plant is a luxuriant grower, healthy and very productive; fruit large and of good color, bright red all over and of good quality. Price, 25c. per dozen, 50c. per 100, \$3 per 1000 .

Nick Ohmer, Per-A fine, fancy market berry and always superb for the table. A giant in size; it is deep red all through, globular, high-flavored, delicious. In healthy vigor and fruitfulness unsurpassed by any other sort. Price, 30c. per dozen, 65c. per 100, \$4 per 1000 .

Echo-Per. Introduced by us. This great table berry has the highest and richest flavor of the natural, wild strawberry which is quite unknown among native varieties. Very productive; fruit large and very largely planted for family use. Price, 35c. per dozen, \$1.00 per 100. 
Clyde, Per.-As large as the Bubach and nearly or quite a week earlier. Seems to do well in all parts of the country. Plants are very vigorous and healthy. Foliage light green in color. Makes extra strong plants. Its roots penetrate far into the ground and thus enable it to withstand severe drought. Price, 25c. per dozen, 50c. per 100, \$3 per 1000.

Glen Mary, Imp.-Very vigorous, enormously productive, of large to very large, bright, deep red berries. Yellow seeds on surface; flesh very firm; light red clear to the center; sweet, rich and high flavored; fine form, bright color, firm and good quality. Price, 25c. per dozen, 50c. per 100, $\$ 3$ per 1000.

Uncle Jim-It is wonderfully productive and the fruit is large. The fruit stalks are exceedingly stout and when borne down with fruit the berries do not lie on the ground and rot like some large kinds before they are ripe enough to pick. They are firm and will stand handling as well as the Gandy. It begins to ripen long before the Gandy and lasis about as long. A variety for home garden where the highest quality is desired. Price, 30c per dozen, 65c. per 100, $\$ 4$ per 1000 .

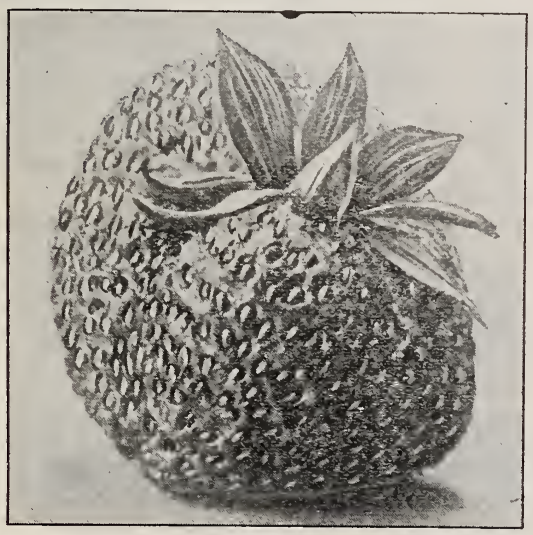

Sample.

Sample, Imp.-This new Strawberry has proven all the originator claimed for it. It is a fine berry of very large size, long in bearing, solid and good. The illustration was drawn direct from a specimen berry. It is quite late to ripen, large to very large in size, crimson color to the core. Very fine for a large berry; strong, vigorous and healthy foliage. Sample is of large size and fine quality, quite firm and continues a long time in fruit. It will yield as many berries as Haverland and average as large as Bubach. Not a weak spot in it. Needs no petting. Price, 25c. per dozen, 50c. per 100, \$3 per 1000 .

Earliest, Per.-It is considered valuable on account of its earliness. More productive than Michaels Early and larger. Price, 25c. per dozen, 50c. per 100, $\$ 3$ per 1000.

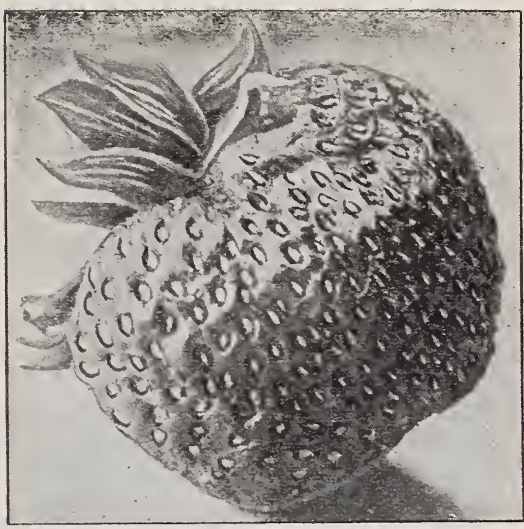

Win. Beit.

Wm. Belt, Per.-A well tested variety that is giving remarkable satisfaction as a large, handsome, productive berry for market or home use. Vigorous, thrifty, heavy plant, producing large crops under good, common culture. Berries extra large, conical, quite uniform in shape; brilliant, glossy red; ripens all over without green tips; good quality; carries well to market and brings highest price. Price, 25c. per dozen, 50c. per 100, \$3 per 1000.

Ryckman (or $\$ 100.00$ ), Per.-This new variety is very highly spoken of by all who have tried it. The plants make a strong growth, free from rust. The originator claims for it superb flavor, size, color, shape and firmness. Heaviest yielder of the giant sort. It is certainly worthy of a careful trial by everyone. Price, 35c. per dozen, \$1 per 100.

Early Beauty-This new berry originated in Iowa. Last year was the first time we fruited it. With us it ripens earlier than any other variety. The fruit is medium to large, about the size and shape of Haverland and fully as productive. Plants make a vigorous growth and are free from blight and rust. It is without doubt the best strawberry of the early varieties. I can heartily recommend this berry to my customers who want an extra early kind. Price, 35c. per dozen, $\$ 1.00$ per 100 .

Bubach, Imp.-Fruit large, handsome, roundish conical, bright scarlet, moderately firm, of fair quality; plant a strong grower, with large, healthy foliage, very productive; succeeds on light or heavy soil. Desirable for home use and near-by market. Has proved one of the best Strawberries. Season early to medium. Price, 25c. per dozen, 50c. per 100, \$3 per 1000 .

We have the following additional varieties which are too well known to require separate description: Crescent, Gandy, Haverland, Jessie, Kansas, Lovetts, Michaels Early, Seaford, Tennessee Prolific and Wilson. Price, 25c. per dozen, 50c. per 100, \$3 per 1000 . 


\section{Red Raspberries}

漗 Note-If you want Raspberry plants sent by mail or express prepaid, add $12 \mathrm{c}$. per dozen, and 40 c. per 50 plants.

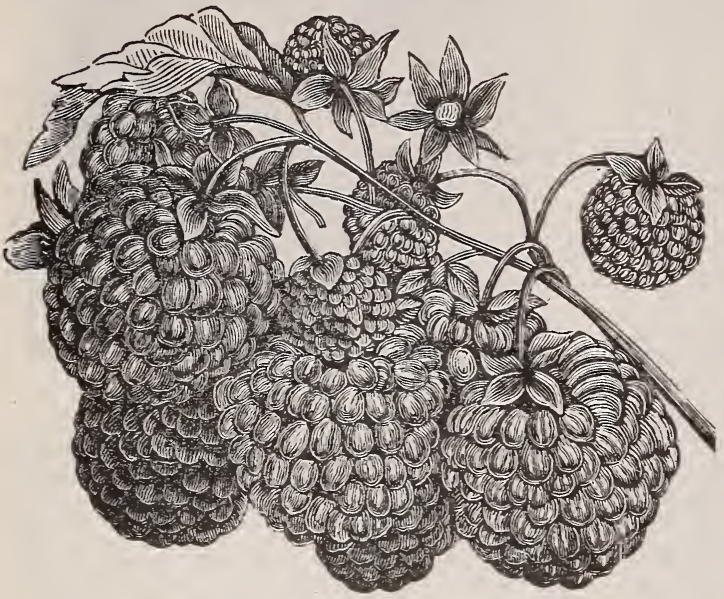

Ruby, Earliest of All.
Ruby - New - This early new berry is just what fruit growers have been looking for. In the Ruby we have earliness, vigor, hardiness, large size and very productiveness. Qualities that will give it a foremost rank. It resembles the Marlboro in color of fruit, but is a stronger grower. It has been grown commercially for six years and today stands ahead of all others as a berry for the growers to plant for profit.
C. G. Velie \& Son (Fruit Growers) in introducing this berry say: "The Ruby Raspberry is a seedling of the well-known Marlboro variety. It partakes of its parent in its habit of growth, but is much more hardy and vigorous. Canes growing six or more feet in height with a good strong foliage. The fruit is born in great quantities, a very prolific bearer and of large size, a good bright color and firm. An excellent shipping berry. It has proved itself to be the most profitable sort wherever tried. Ripens with the earliest." Do not fail to plant the Ruby. Price, 8c. each, 4 for 25c, 60c. per dozen, $\$ 3$ per 100 , $\$ 20$ per 1000 .
What Large Fruit Growers Say About Ruby. Orange Co, N. Y. Nov, Io, I905 Dear Sir:- We have grown the Ruby Raspberry for the past two years and find it a prolific bearer. The canes grow large and healthy. The fruit is very large and ships exceedingly well, being very firm. We think it a very valuable market berry as it starts to ripen ahead of any other variety and continues through a long fruiting season. WM. C. YOUNG \& SON.

U1ster Co., N. Y., Nov. II, 1905.

Dear Sir:-We find the Ruby Raspberry just as you represented it. We set out 2000 plants and the first year picked 4500 pints. We consider it the best berry to plant. J. \& E. I,AWSON.
Ulster Co, N. Y., Nov. 16, I905. Dear Sir:-I think the Ruby Raspberry the very best variety grown, as it is healthy, has a good color, is a good shipper and free picker. I picked this last summer from Iooo plants, one year old, 4500 pints. HENRY COUTAN'T.

Ulster Co., N. Y., Nov. II, I905.

Dear Sir:-During the past season from 3500 hills of the Marlboro Raspberry. I picked 3000 pints, while from 950 hills of the Ruby I shipped 4750 pints from a two-yearold patch. They are very vigorous and need planting farther apart than other varieties. They are firm and stand up well in the market. When Marlboros sold for 6 cents per pint, I received from Io to I2 cents for Rubys. NICHOLAS PHELAN.
Loudon-A red mid-season berry. Large fruit, beautiful, rich dark crimson color, good quality, enduring winter without protection and without injury to the very tips. It stands shipping the best of any variety, and will remain on bushes the longest without injury. Price, 8c. each, 60c. per dozen, \$2 per 100.

King-An early red raspberry; round, medium size, light crimson, firm and of excellent quality. A seedling of Thompson and ripens about the same time, but larger and more productive. It is far ahead of Loudon or Millers on our ground. Price, 7c. each, 60c. per dozen, \$2 per 100.

Marlboro-Iarge size, light crimson color, good quality and firm. Vigorous and productive. One of the best, well tested, large early berries for the North. Price, 5c. each, 40c. per dozen, $\$ 1.50$ per $100, \$ 10$ per 1000.

Golden Queen-Yellow Variety-This variety is almost identical with Cuthbert, except in color. Fruit large, productive; quality first-class. It is beyond doubt the finest and most profitable yellow berry grown. Price, 7c. each, 60c. per dozen, $\$ 2$ per 100.

Schaffer-This is the best-known of the purple Raspberries. It is very vigorous, large and productive. It picks easier than Columbian, but is not so large or firm. Price, 5c. each, 40c. per dozen, $\$ 1.50$ per $100, \$ 10$ per 1000 . 


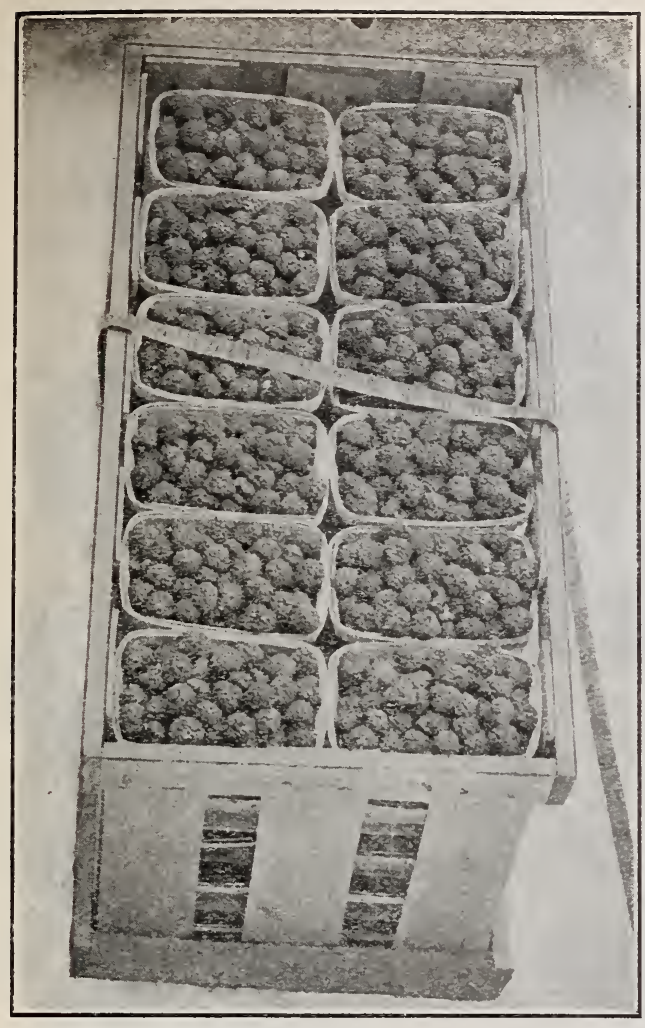

Herbert.

Herbert (Iron-clad Variety)-Stood 30 degrees below zero without freezing a tip. A chance seedling that sprang up about 14 years ago in the garden of R. B. Whyte, one of the most prominent and best-known amateur horticulturists in the city of Ottawa, Canada It has undergone a thorough test beside all the older varieties as well as all the later productions, and has completely outclassed them all for hardiness. The cane is very strong and vigorous, slightly prickly, leaves large and healthy, and has never been affected by Anthracnose or disease of any kind. Fruit bright red, somewhat oblong. The largest of all red raspberries, larger than the Cuthbert or Loudon. Flavor very sweet and juicy. The very best for table use. Enormously productive, will bear twice the crop of either the common Cuthbert or Loudon under the same conditions. Season five or six days earlier than the Cuthbert. Holds its size well to end of season. Price, 40c. each, \$4 per dozen, \$25 per 100.

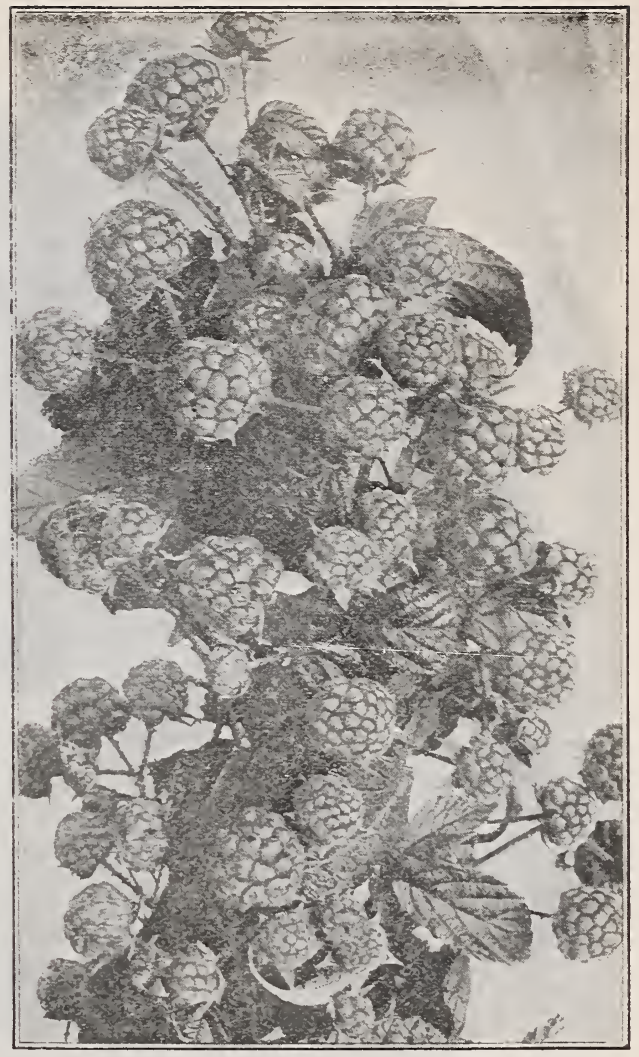

Columbian, Very Productive.

Columbian-This great berry is believed to be a cross between Cuthbert and Gregg, and is superior and larger than Schaffer, which it resembles in type and color. Te recommend it for all garden and general planting. For canning purposes it is undoubtedly the very best Raspberry in cultivation, yielding as high as 8,000 quarts per acre. Unlike some kinds, it does not go to pieces in the process of canning, and does not shrink. It is very popular and is known from Maine to California. A dozen strong plants will supply a family with fruit, as it grows from eight to twelve feet high, and in fruiting season its branches are covered with fine, large crimson berries. Perfectly hardy, and grown largely for evaporating, retaining color, form and flavor remarkably. Price, 5c. each, 40c. per dozen, $\$ 1.50$ per $100, \$ 10$ per 1000 .

What the Horticultural Department of the Experimental Farm at Ottawa, Canada, Says About the Herbert

We have closely observed the Herbert Raspberry growing on the farm for the last few years and consider it ahead of cuthbert, which is classed as the best red raspberry now on the market. As judge at the Ottawa Horticultural Society's shows for the last six years, I have always been more favorably impressed with the fruit of the Herbert raspberry than any others, and have always awarded it first prize. 


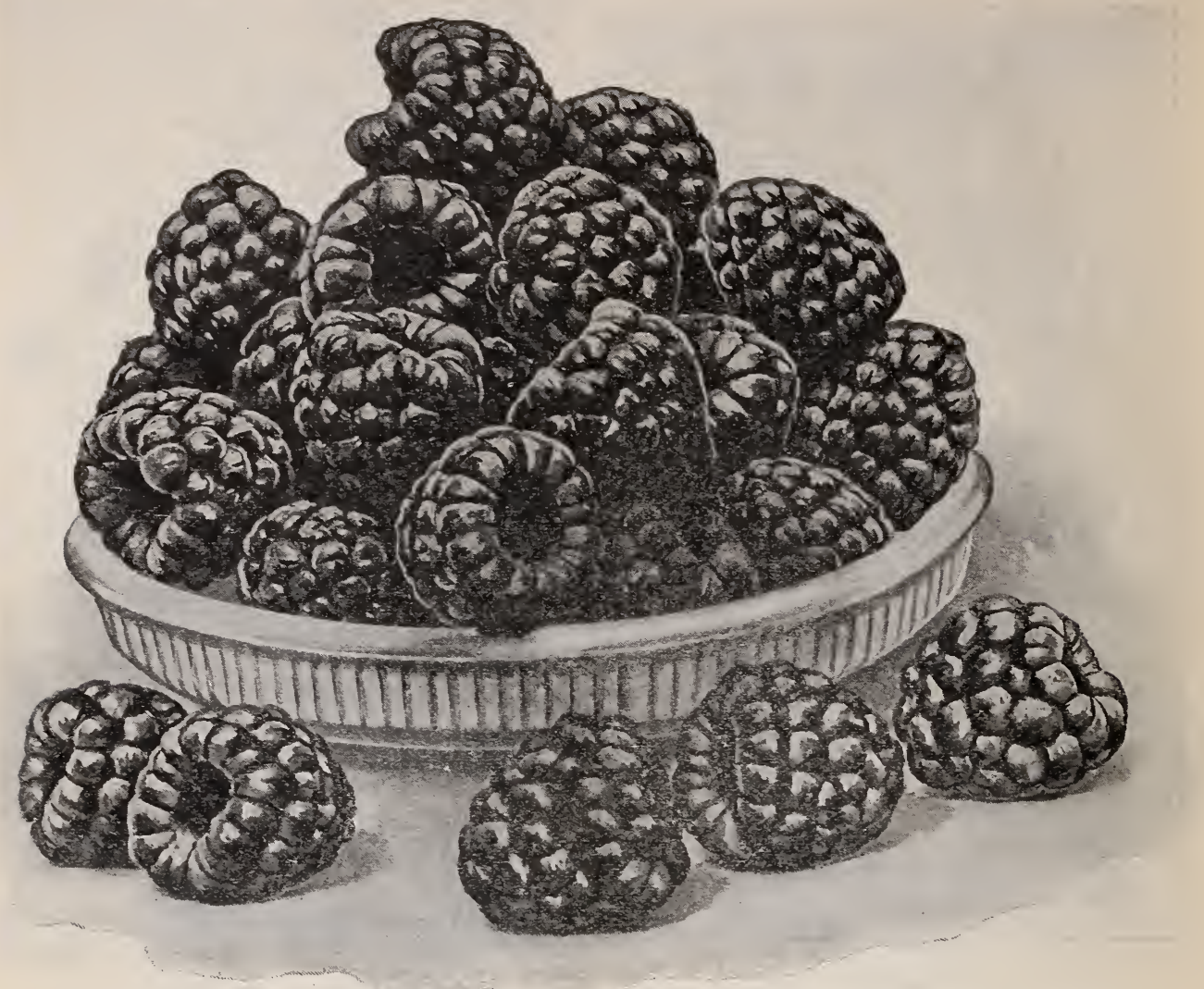

Wood's Improved Cuthbert, Most Profitable Market Raspberry.

Cuthbert, Wood's Improved-Has excelled all other late varieties of Red Raspberries. For the past ten years I have propagated it from my very best busher and now have Cuthberts far ahead of the average. One fruit-grower who saw my fruit in 1901 ordered 30,000 plants of me the next year. In 1905 his erop of Cuth. berts averaged him over $\$ 300.00$ per acre. No fruit-grower can afford to omit planting Wood's Improved Cuthbert, and surely no person who has a garden should attempt to get along without this Red Raspberry. If you need Raspberry plants it pays to buy the very best stock. The Cuthbert is the leading market variety all over the country. Remarkably strong, hardy variety; stands Northern winters and. Southern summers equal to any. Berries very large, measuring three inches around; conical, rich crimson, very handsome; so firm they can be shipped hundreds of miles in good condition; flavor sweet, rich, luscious. Price, 5c. each, 30c. per dozen, \$1 per 100, \$7 per 1000.
Mills (The Mortgage Raiser) - The demand for Mills for the past three years has been greater than the supply. It seems impossible to grow enough plants for the demand. We consider it the best Black Raspberry we have ever grown. It is perfectly hardy, extremely large, large as the Cumberland, very firm. It is the most productive of all Black Raspberries we have tried. It brings the highest price of any in the market. It has given such immense satisfaction to the fruit-growers in Western New York that it is almost impossible to buy any plants from fruitgrowers who have it. Price, 8c. each, 60c. fer dozen, \$2 per 100, \$15 per 1000 .

Ohio-Tery valuable for drying. Plant hardy and prolific. Fruit of good size and productive. Price, 5c. each, 40c. per dozen, $\$ 1.50$ per 100, \$10 per 1000 .

Palmer-Ripens early; fruit firm and of large size. Superior quality, free from bloom, making it very attractive in fruit box; brings the highest market price. Strong grower, very hardy, healthy foliage and in some localities stands at the hear for productiveness. Price, 5c. each, 40c. per dozen, \$1.50 per 100, \$10 per 1000 . 


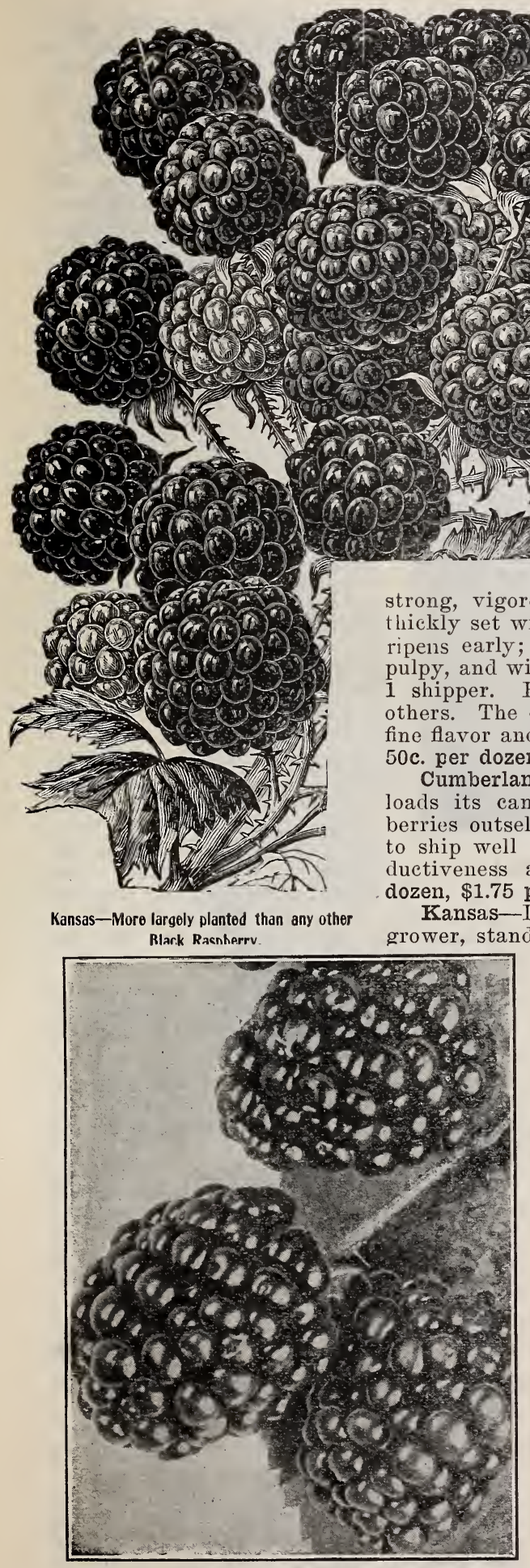

Rathbun, largest of all Blackberries. See Bargain Prices.
Gregg - V e r y large, wants good soil; fruit very firm. It is the favorite for gene r a 1 planting when a late variety is needed. Price, 5c. each, 40c per dozen, $\$ 1.50$ per $100, \$ 10$ per 1000 .

Black Diamond -This variety is fast becoming a favorite. For the past three seasons we have not had near e nou gh plants to supply the demand. It is one of those varieties that the more you get of it $\mathrm{the} \cdot \mathrm{more}$ you want. M a k s strong, vigorous canes with numerous side branches all thickly set with fruit spurs. Berries about size of Gregg, ine sweetest berry known. Fine flavor, shipper. For drying and evaporating it excels all The dried fruit is jet black, retains the richness, fine flavor and sweetness of the ripe fruit. Price, 8c. each, c. per dozen, $\$ 1.75$ per 100, \$12 per 1000 .

- A mammoth mid-season blackeap that outsell all others of their season, are firm enough ss among the best. Price, 8c. each, 50c. per $\$ 1.75$ per $100, \$ 12$ per 1000 .

It is of the largest size; strong, vigorous extremes of drought and cold and bearing immense crops. Early, ripening just after Palmer. Berries size of Gregg, of better color; jet black and almost free from bloom; firm, of best quality, presents a handsome appearance, and brings highest price in market. Price, 5c. each, 40c. per dozen, $\$ 1.50$ per $100, \$ 10$ per 1000 .

\section{BLACKBERRIES}

If you want Blackberry plants sent by mail or express prepaid, add $12 \mathrm{c}$. per doz., and $40 \mathrm{c}$. per 50 plants.

Rathbun-On account of its superior character those accustomed to the old varieties would scarcely recognize it for a blackberry. The plant is very vigorous, branching naturally, producing fruiting canes very freely and an abundance of large, luscious fruit. It suckers but slightly, the roots are strong and penetrate deeply into the soil, a valuable characteristic in dry seasons and locations. The fruit is large and handsome, intense black, with a very high polish, and without any hard core, juicy, high flavored; of such a superior quality that it is in a class by itself. For table use, for canning, or for culinary purposes it is equally desirable. Bargain price, 5c. each, 40c. per 


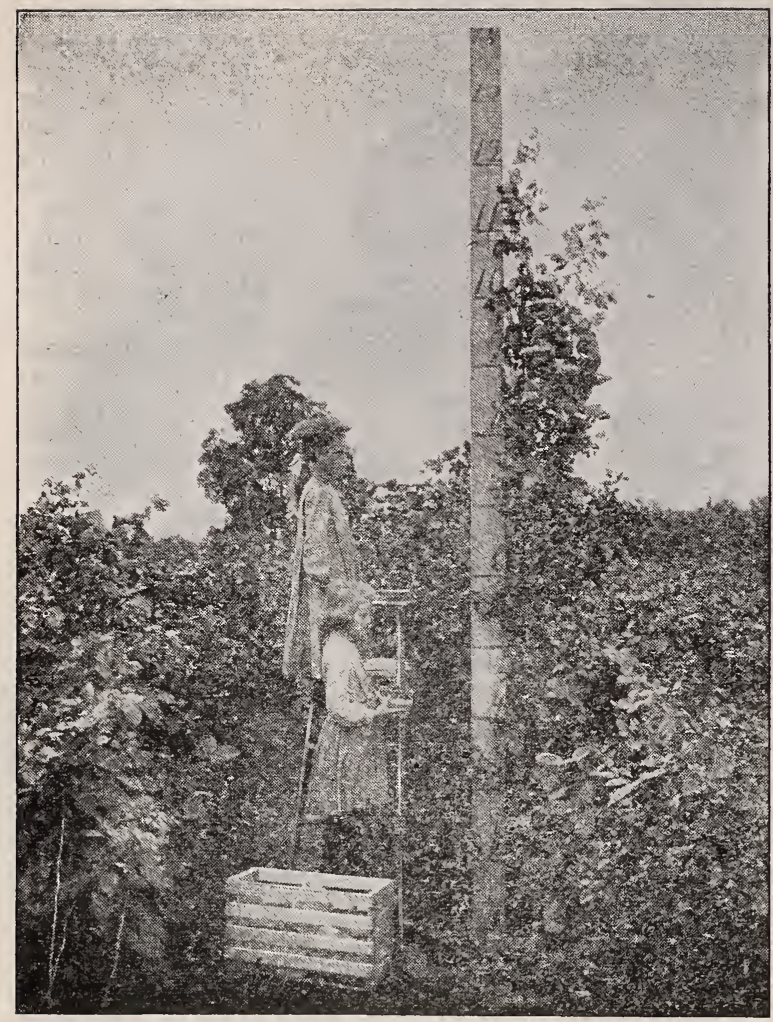

Blowers-2,694 Berries on This Bush.
Snyder-This popular, hardy and profitable blackberry is known everywhere and planted largely. Where other varieties have entirely failed it has proved perfectly hardy. It is also grown in localities where hardiness is not the prime and first consideration, because of its productiveness and general adaptability to all locations. It is the blackberry for every fruit-grower desiring to make a start in blackberries, but has not the means to buy the high-priced varieties. Keep the soil rich with barnyard manure and wood ashes and no one will complain of the size of the Snyder. We have grown it for twenty years and shall continue to plant it, as it usually gives a good picking where many other varieties have failed. This is the standard sort for the North and Northwest, and is very popular. Price, 5c. each, 40c. per dozen, $\$ 1.50$ per $100, \$ 10$ per 1000.

Minnewaski-One of the largest and most productive; on trial several years and receives most favorable reports from nearly all sections. Fruit glossy, black, tender, juicy, sweet, fine aromatic flavor. Remarkably productive and hardy. One of the best for

Blowers-"The giant of all blackberries" is now beyond the stage of experiment and is the leading variety where known. It has all the good points of a perfect blackberry; a mammoth grower, 12 to 14 feet high, and is enormously productive. Big, glossy and luscious berries. Overshadows all others with a record from $1 / 4$ acre, 2,347 quarts, over 73 bushels, netting $111 / 4$ cents per quart, or over $\$ 1,056.00$ per acre.

In $1905 \mathrm{Mr}$. Blowers, the originator, sold his crop in Buffalo, N. Y., for \$3.52 per 32-quart crate, or 11c. per quart. On one bush they counted 2,694 berries. They are of the best quality and bring the best price. They bear longer than any other kind. Bushes are so strong and tall that they can carry a great crop. It is an ironclad variety, never winter kills. One plant enough for a family garden. Price, 15c. each, 2 for 25c., \$1 per dozen, \$5 per 100.

\footnotetext{
Hon. John S. Lambert, Supreme Court Judge. "I saw a sample of Blackberry bush known as the Blowers Blackberry, something over I3 feet high and loaded with the most delicious fruit I ever saw. It was a surprise both in the size of the bush and berry, as well as quantity of fruit, as I had never seen or heard of anything that approached this display. In my opinion it will absorb all other varieties."
} market and home garden; early. Price, 8c. each, 60c. per dozen, $\$ 2$ per $100, \$ 15$ per 1000 .

Ohmer-A valuable, late, market sort; large; good quality; very productive. Price, 8c. each, 60c. per dozen, \$2 per 100.

Farly Harvest-Very early; productive; fruit medium size, bright, glossy, black; good shipper. Best on sandy soil. Price, 5c. each, 35c. per dozen, \$1.25 per $100, \$ 8$ per 1000 .

Eldorado-Hardy as Snyder. Cultivated twelve years and never winter killed. H. E. VanDeman, National Pomologist, says: "Never have I tasted anything equal to Eldorado.", We have fruited it and find it hardy and fine. Price, 8c. each, 60c. per dozen, \$2 per 100.

Erie-Strong growers, will produce large crops on poor soil. Fruit of largest type, very uniform. Price, 5c. each, $40 \mathrm{c}$. per dozen, $\$ 1.50$ per 100, $\$ 10$ per 1000 .

Farly King-An extra early and exCanes of strong growth, as hardy as Snyder, and very prolific. Highly recommended by the experiment stations. Price, 7c. each, 50c. per dozen, $\$ 1.50$ per $100, \$ 12$ per 1000. ceedingly hardy variety of great merit. 


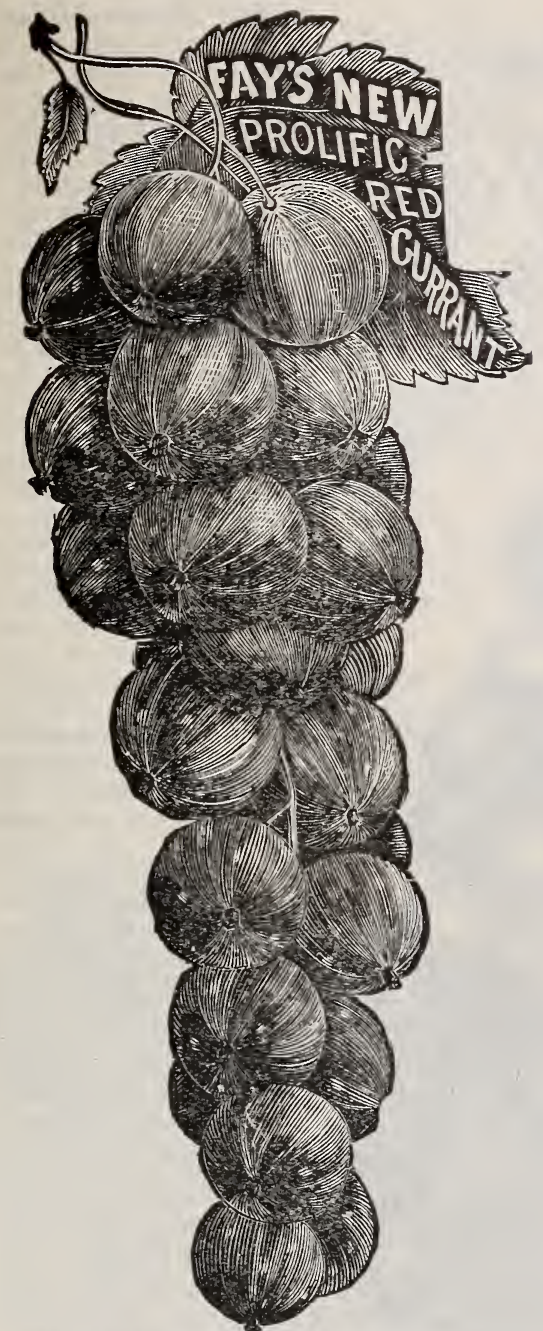

See Bargain Price of Fay Currants.

Fay's Prolific-The leading market variety; extra large stems and berries uniform in size. Easy to pick. Exceedingly productive. No variety of fruit has ever made as quick a jump into popular favor. The demand for Fays seems to increase each year, and for the past ten years we have sold more Fay's Prolific Currants than all the others put together. At the present time I have an extra good stock and am offering them at bargain prices while my stock lasts. Bargain price of Fay's Prolific Currants, two year old plants, 5c. each, 40c. per dozen, $\$ 2$ per 100, $\$ 17.50$ per 1000. One year plants, 25c. per dozen, $\$ 1.50$ per 100 .

We also have these additional two year old currants, 5c. each, 50c. per dozen, $\$ 2.50$ per 100. La Versailles, Prince Albert, North Star, Victoria, Red Dutch, Black Champion and Black Naples.
White Grape-The Iargest and most productive white currant grown. Flavor sweet and very fine for the table. Not desirable for the general markets because people don't seem to take to white fruits. The best table currant. Price of two year old plants, 8c. each, 50c. per dozen, $\$ 3$ per 100.

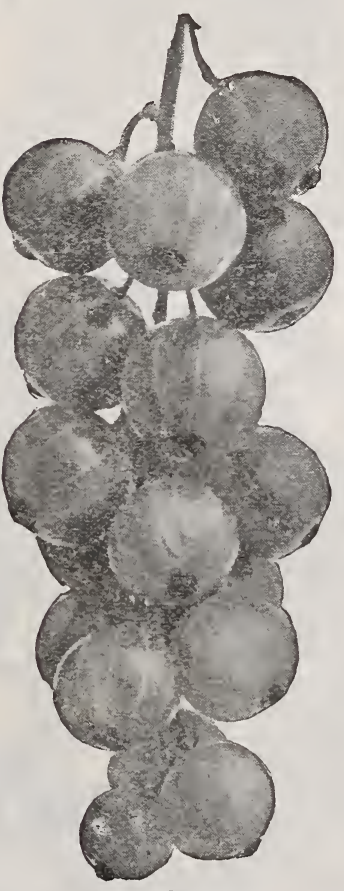

Perfection
P e r f e ction - T h is grand New Currant originated by a f r u it grower near Rochester, N. Y. A cross between the Fay and White Grape. Awarded the Barry M e d a I - the fifty dollar gold medal of the Western N. Y. Horticultural Society, July, 1901, after three years' trial. First fruit to receive this grand prize. Also received highest prize given any new fruit at the PanAmerican Exposition. Is very highly endorsed by Prof. S. A. Peach, $\mathrm{H}$ or ticulturist of N. Y. State Agricultural Experiment Station at Geneva, after four years' trial there in competition with sixty varieties. Color, bright red; larger than Fay; rich, mild, sub-acid, with few seeds and good quality. We are one of the very few Nurserymen having the right to sell Perfection. Price, 50c. each, \$5 per dozen.

Pomona-Medium size, clear bright rer, excellent quality; hangs long time after ripe; holds up well on market; is one of the best for shipping; easily and cheaply picked. Holds an unparalleled record for actual acreage yield in ordinary field culture. Price of two year old plants, 5c. each, 50c. per dozen, \$2.50 per 100.

President Wiider-This variety is very popular with fruit-growers. It is one of the strongest growers and very productive. Bunches of berries very large, bright attractive red color and hangs on bushes longer than any other variety. Not as large as Fays but longer bunches and better quality; much less acid. Ripens same time. Price of two year old plants, 5c. each, 50c. per dozen, $\$ 2.50$ per 100 . 


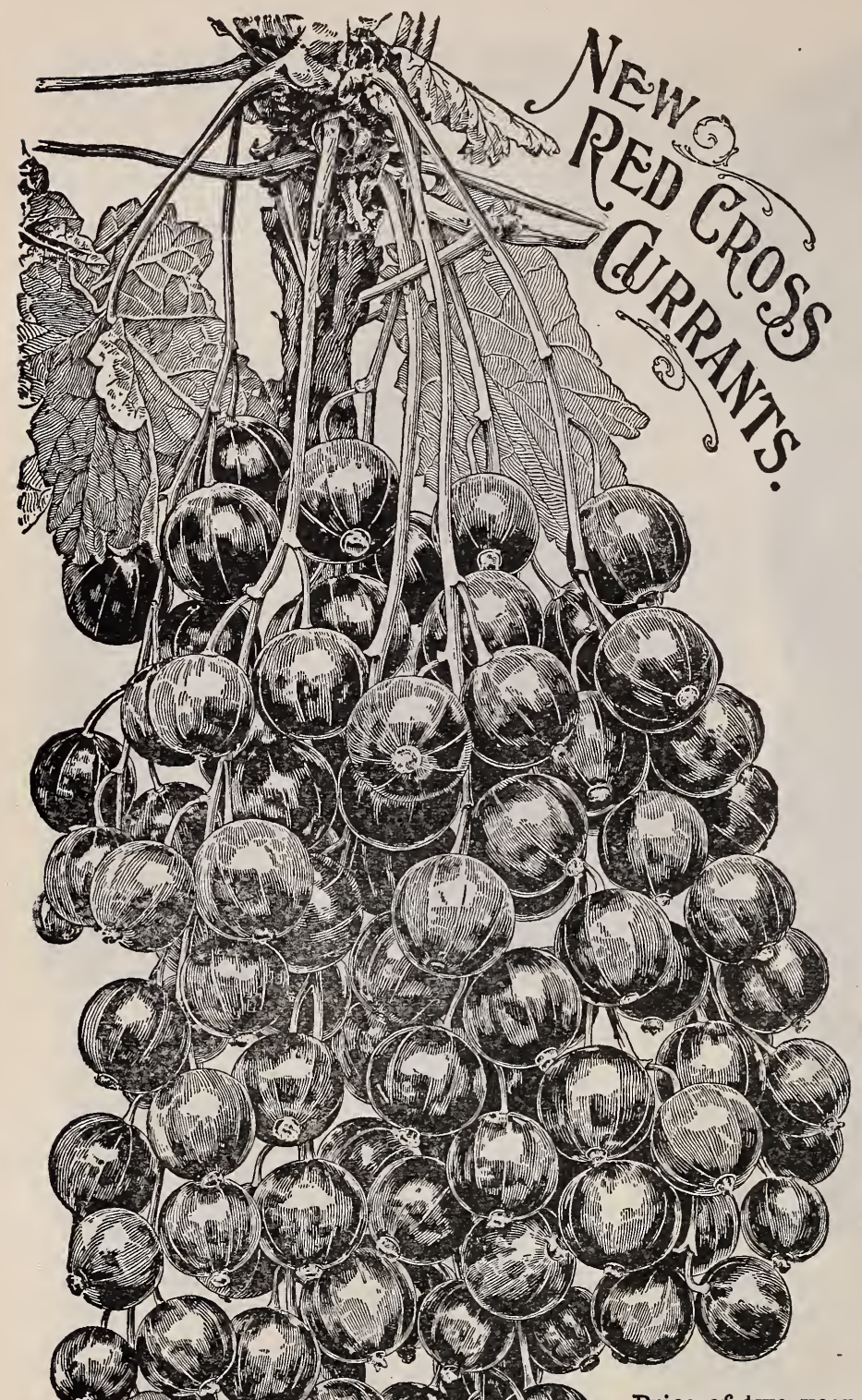

Red Cross-Greatest of all currants. Rural New-Yorker says: "Reil Cross is the best of all old or new currants for mid-season.", N. Y. Experiment Station says it is large and productive. The masses of fruit were so dense as to completely hide the bearing canes from view. Jacob Moore says this is a peculiarity of the Red Cross. I have cut off some of the branches thus heavily laden and sent them to the Rural New-Yorker, C o un try Gentleman, as well as to l e a d ing pomologists. These people have said they never saw anything to equal the Reil Cross as shown by specimen branches. E. W. Reid says he is remarkably impressed with this variety, especially for its large size and productiveness, it being much superior to Fay's in every respect. I have picked stems of this currant seven inches long with 23 to 26 currants upon a single stem. It is the most vigorous grower of all currants I have tested. It seems as though this variety would create an epoch in currant growing. You can not make any mistake in planting tho Red Cross Currant. The plants I offer are well rooted and very strong. Now is a good time for planting currants, gooseberries and raspberries, as well as many other varieties. Strong plants. Price of two year old plants, 5c. each, 50c. per dozen, $\$ 3$ per 100 . One year plants, $25 \mathrm{c}$. per dozen, $\$ 2$ per $100, \$ 18$ per 1000 .

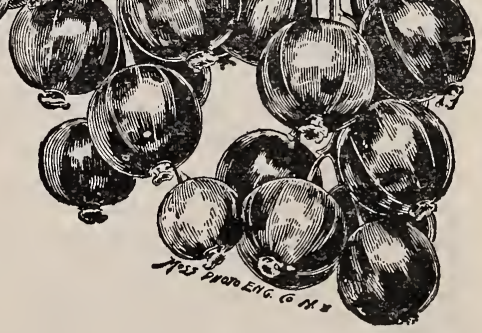

Cherry-Strong grower, fruit very large, sometimes measuring one-half inch in diameter. Should have good soil and thorough cultivation. Price of two year old plants, 5c. each, 50c. per dozen, $\$ 2.50$ per 100.

Lee's Prolific (Black)-Considered one of the best black Currants. Fruit large; produces abundantly. Never attacked by insects of any kind. Valuable for making jellies, jam and wine. Price of two year old plants, 5c. each, 50c. per dozen, $\$ 3$ per 100. 


\section{GOOSEBERRIES}

If you want Gooseberries sent by mail or express prepaid, add 12c. per dozen; 40c.per 50 plants.

Downing-One of the oldest and best. Large, handsome, pale green, of splendid quality, for both cooking and table use. Vigorous grower and usually free from mildew. Price of two year old plants, 8c. each, 60c. per dozen, \$5 per 100.

Houghton-A very productive, hardy berry of medium size, and for general purposes one of the best. Price of two year old plants, 7 c. each, 50c. per dozen, $\$ 4$ per 100.

Industry-An English variety. It is very popular in England. Fruit is large size, color dark red. The best of all English varieties in this country. Price of two year old plants, 15c. each, $\$ 1.50$ per dozen, \$10 per 100.
Pearl-Best American variety-a cross between Houghton and a large English variety; very hardy, free from mildew, superior in size and quality, and more productive than Downing; is likely to supersede this standard sort. From many flattering testimonials we take pleasure in recommending this variety as one of the best. Price of two year old plants, 8c. each, 60c. per dozen, \$5 per 100.

Red Jacket-An American seedling of large size; smooth, prolific and hardy, of best quality. Well tested over a wide extent of territory with all leading varietics. A wonderful cropper; bright, clean, healthy foliage. Price of two year old plants, 10c. each, \$1 per dozen, \$7 per 100.

Rhubarb (or Pie Plant)-for Family or Market. We have millions of well-rooted Rhubarb plants for sale. Have you a bed of Rhubarb in your garden? If not, do not fail to start one this spring.

Rhubarb (Myatt's Linnæus) - Early, tender and very large; known as the sweetest of pie-plants. Price of two year old plants, 8 cents each; 50 cents per dozen; $\$ 3.00$ per 100 . One year plants, 5 cents each; 35 cents per dozen; $\$ 2.00$ per 100 . Extra large, three year old plants for forcing in greenhouses, $15 \mathrm{c}$, each: $\$ 1.00$ per dozen; $\$ 5.00$ per 100 .

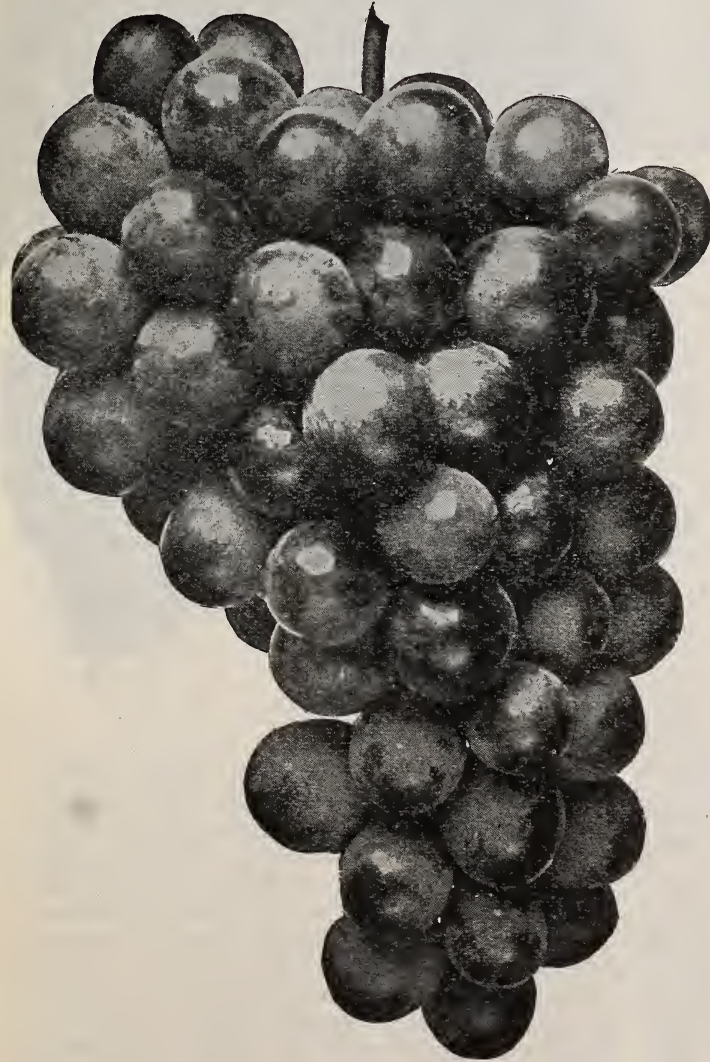

McKinley Early Grape.

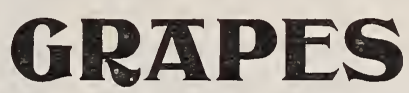

Note. If you want Grapes sent by mail or express, prepaid, add 12c. dozen; 40c. per 50 plants.

IcKinley Early, New-If you want extra quality and a very sweet grape, plant the McKinley Farly. It differs from all other grapes in the fact that the pulp has no acid and parts easily from its few seeds, the skin has no puckery taste. It is the coming early grape for the market. It is a cross between Niagara and Moore's Early. Strong grower, bunches large, compact and handsome; berries large and oval like Malaga grapes; green at first, turning to yellow when fully ripe; very sweet. Extra quality; a good shipper; remarkable keeper, will hang on vines sound and perfect for weeks after ripe. All grape growers will appreciate the value of an early white grape as large and productive as Niagara and fully ten days earlier, with the richest flavor of any grape on the market. Price of two year old plants, 50c. each, 6 for $\$ 2.50, \$ 5$ per dozen. One year plants, 35c. each, 6 for $\$ 1.80, \$ 3.50$ per dozen. 


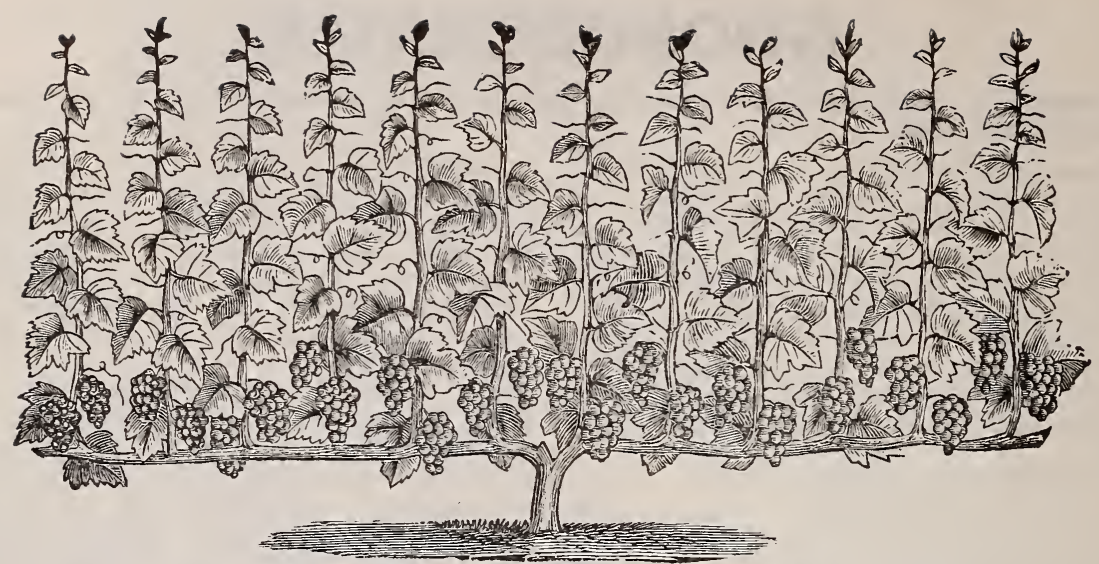

Concord-Most Profitable Hardy Market Grape. (See Bargain Price.)

Concord-This hardy black grape is decidedly the most popular grape in America and is more largely planted than all the other kinds put together. Bunch large, shouldered, compact; berries large, covered with a rich bloom; skin tender but sufficiently firm to carry well to a distant market; flesh juicy, sweet, tender. Vine a strong grower, very hardy, healthy and productive. For general cultivation the most reliable and profitable variety. Price of strong two year old vines, $5 \mathrm{c}$. each, $48 \mathrm{c}$. per dozen, $\$ 1.98$ per $100, \$ 17.50$ per 1000 . One year old vines, 36c. per dozen, $\$ 1.48$ per $100, \$ 12.85$ per 1000 .

Campbells Early (Black)-Strong grower, with large, healthy foliage; productive, its keeping and shipping qualities are equalled by no other early grape. Ripens with Moore's Early, but will keep in sound, perfect condition long after that variety is gone. Bunch and berry large, glossy black, with blue bloom, sweet an.l juicy, seeds few and small, part readily from the pulp. Stands at the head of early black grapes for quality. Price of strong two year vines, 15c. each, $\$ 1.50$ per dozen, $\$ 10$ per 100 . One year old vines 10c. each, $\$ 1$ per dozen, $\$ 8$ per 100.

Moore's Early (Black)-Bunch and berry large, round, with heavy blue bloom; vine exceedingly hardy. Its earliness makes it desirable for an early market; its hardiness particularly adapts it to Canada and northern portions of the Uniter States. Price of strong two year vines, 7c. each, 60c. per dozen, $\$ 3.50$ per $100, \$ 30$ per 1000. One year vines, 5c. each, 48c. per dozen, $\$ 2.50$ per $100, \$ 20$ per 1000 .

Worden-A seedling of Concord. Handsome, early, black, healthy, vigorous and productive, with large, longer bunches; better in quality and ten days earlier than its parent. Price of strong two year vines, 7c. each, 54c. per dozen, $\$ 2.85$ per $100, \$ 26$ per 1000 . One year vines, 5c. each, $44 \mathrm{c}$. per dozen, \$2.15 per 100, \$20 per 1000 .

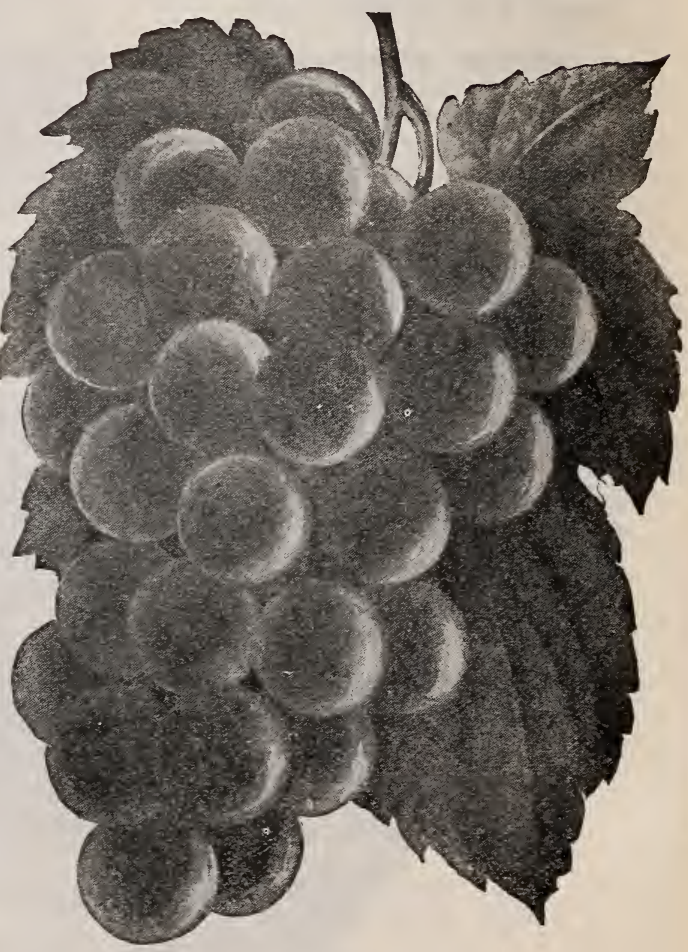

McPike.

McPike-This mammoth black grape has been exhibited in all parts of the country. Its great size, fine flavor and beauty creating quite a sensation. The bunches are large, even and compact, the berries sometimes three inches in circumference, covered with a rich bloom; ripening evenly and keeping well. The vine is very strong and thrifty in growth with great, leathery leaves. Ripens before Concord. Price of strong two year vines, 15c. each, $\$ 1.50$ per dozen, $\$ 10$ per 100 . One year vines, 10c. each, \$1 per dozen, \$8 per 100. 


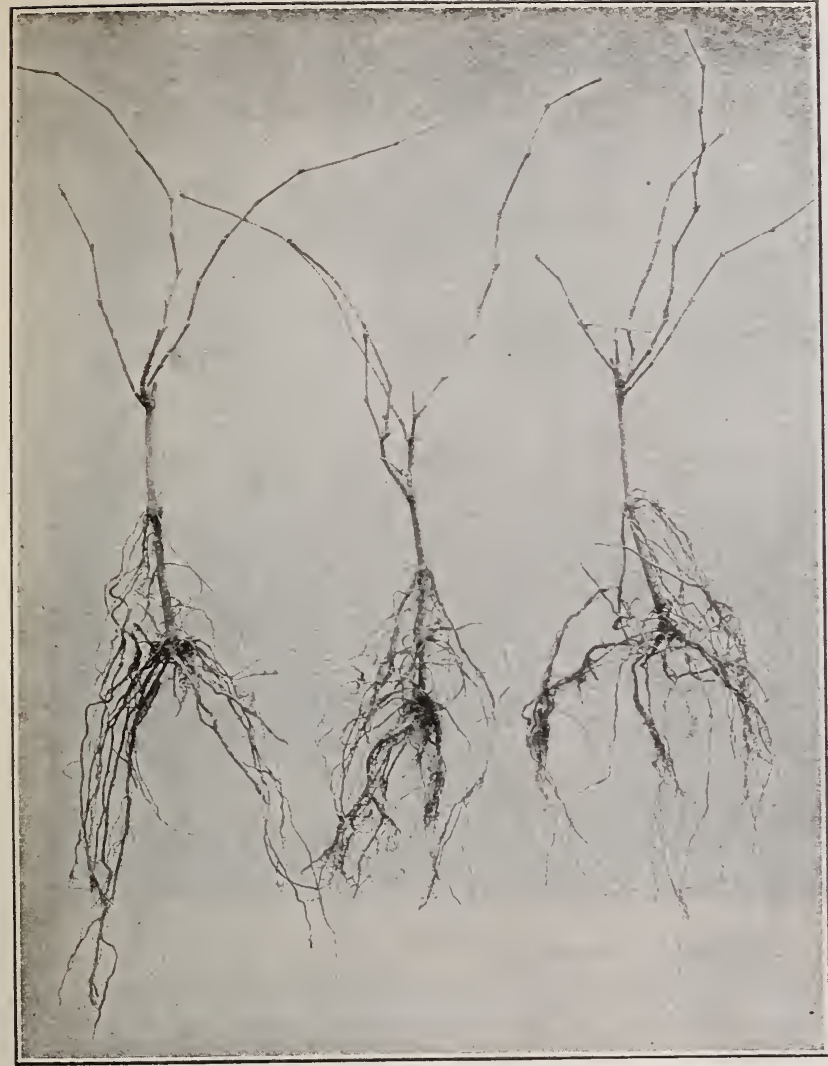

Two Year Old Grape Vines, Showing the Remarkably Fine System of Roots Produced at Woodlawn Nurseries.
ALICE - New Red Grape, ripens with Concord. Keeps all winter, plump and fresh as when gathered without shelling or loss of flavor. Hardiest in vine and fruit, strong grower, free from mildew or disease; immense yielder; 40 to 60 clusters per vine; high quality, rich in sugar, has stood the test for ten years under all conditions; is today one of the most valuable grapes before the American vineyardist. $\mathrm{O}$ u r stock is very limited; order early. Price, 25 cents each, $\$ 2.50$ per dozen.

Dr. F. M. Hexamer, Editor American Agriculturists, N. Y., writes:

The samples of A lice Grapes arrived in excellent condition. They were tasted on March Isth by several persons of refined taste and all declared they had never tasted such delicious grapes at this season of the year.
Agawam-(Rogers' No. 15) (Red)Berries very large, thick skin, pulp soft, sweet, sprightly, very vigorous, ripens early. Price of strong two year vines, $10 \mathrm{c}$. each, 75c. per dozen, $\$ 3.50$ per 100, $\$ 30$ per 1000. One year vines, 6c. each, 50c. per dozen, $\$ 2.50$ per 100 , $\$ 20$ per 1000 .

Brighton-Perhaps best Red Grape in cultivation. Bunch large, compact; strong grower and very productive; quality good. Price of strong two year vines, $10 \mathrm{c}$. each, 85c. per dozen, $\$ 4.50$ per 100 . One year vines, 6c. each, 60c. per dozen, \$3 per 100.

Pocklington-Or "Golden Pocklington," retains its popularity, being one of the largest and most showy white grapes of the Concord type yet introduced. Price of strong two year vines, 8c. each, 60c. per dozen, $\$ 3$ per $100, \$ 27.50$ per 1000 . One year vines, 5c. each, 44c. per dozen, $\$ 2.15$ per 100, \$20 per 1000 .

Niagara-Occupies the same position among white varieties as Concord among black; leading profitable market sort. Bunch and berries large, greenish white, pale yellow when fully ripe. Skin thin, but tough; quality much like Concord. Price of strong two year vines, 8c. each, 60c. per dozen, $\$ 3$ per $100, \$ 27.50$ per 1000 . One year vines, 5c. each, 44c. per dozen, $\$ 2.15$ per 100 , $\$ 20$ per 1000 .

Salem-(Rogers' No.53)-Bunch large, compact; berry large, round, coppery red, tender, juicy; slight pulp; one of the best. Ripens with Concord. Vine healthy, vigorous and productive. Price of strong two year vines, 10c. each, 85c. per dozen, $\$ 4.50$ per 100 . One year vines, 6c. each, 60c. per dozen, $\$ 3$ per 100.

Delaware-Red, finest flavor. Bunch and berry small, compact; sweet, thin skin; slow grower; requires good soil and careful handling. Price of strong two year vines, 10c. each, $\$ 1$ per dozen, $\$ 5$ per 100. One year vines, 7c. each, 65c. per dozen, $\$ 3.50$ per 100 .

Diamond-Leading early White Grape, ripening before Moore's Early. White, rich yellow tinge; juicy, few seeds, almost free from pulp; excellent quality; above medium size, adheres firmly to stem. Like Concord in growth, hardiness and foliage. Fine for both market and garden. Price of strong two year vines, 8c. each, 60c. per dozen, $\$ 3$ per $100, \$ 27.50$ per 1000 . One year vines, 5c. each, $44 \mathrm{c}$. per dozen, $\$ 2.15$ per 100, \$20 per 1000 . 


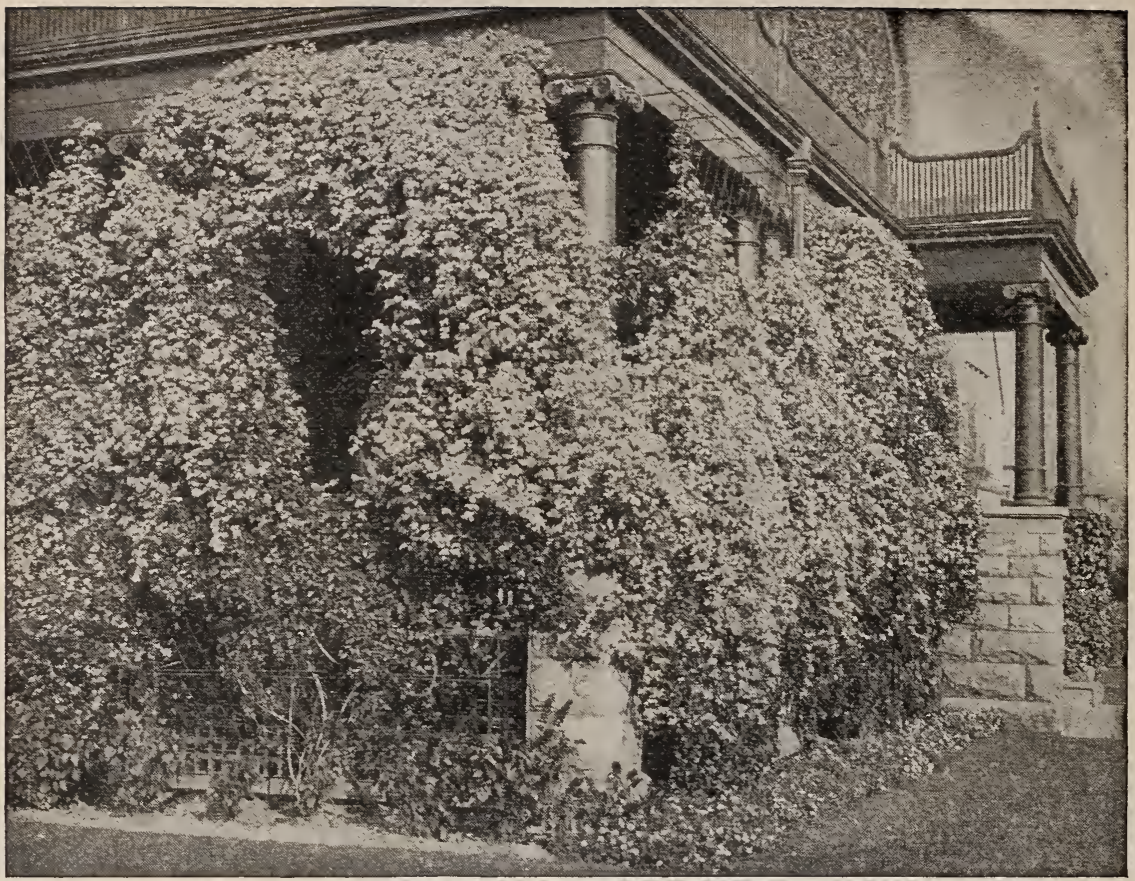

\section{Paniculata Clematis.}

Clematis Paniculata (New SweetScented Japan Clematis)-No recent introduction has met such ready sale and given so perfect satisfaction. Grows and thrives anywhere; a very rapid grower, profuse bloomer. Flowers pure white, borne in large clusters, converting the

plant into a perfect mass of white. Its extreme hardiness, bright green foliage and delightfully fragrant flowers make this one of the finest hardy climbing plants in cultivation. Extra strong two year plants, 25c., five for $\$ 1$.

If sent by mail add 5c. to each plant.

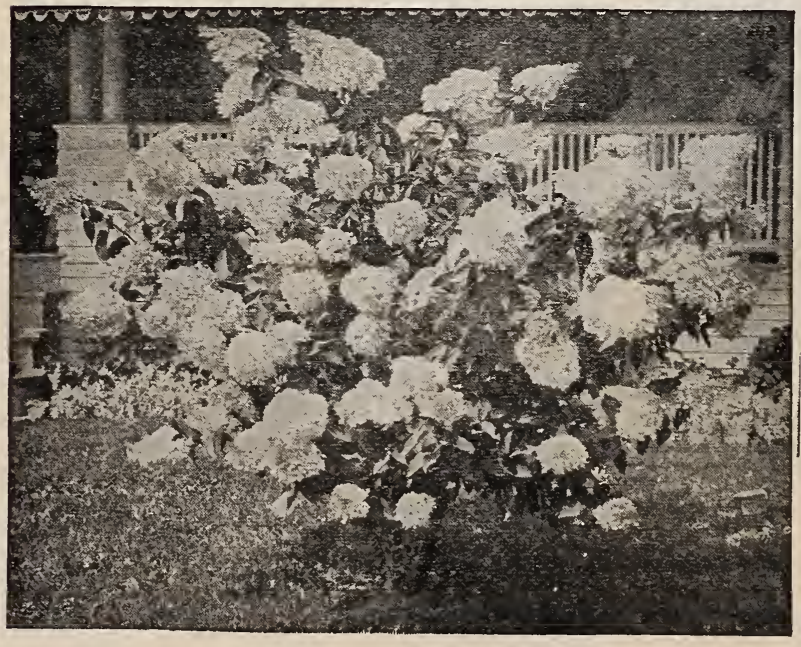

Hardy Hydrangea Paniculata Grandiflora. King of Shrubs.
Hardy Hydrangea Paniculata Grandiflora - Too well-known to require description. Probably the most popular of all shrubs. Blooms in August and September, when we have few shrubs in bloom. Flowers white, in pyramidal panicles often a foot in length. Excellent plant for masses or single specimen. Large plants, 25c. each, $\$ 2.50$ per dozen.

If sent by mail add $5 c$. to each plant.

Snowball-A well-known favorite shrub, with globular clusters of white flowers frequently borne in clusters of five or six. Price, 25c. each. 
Weigela Rosea-This is one of the most charming shrubs in cultivation; it cannot be too highly recommended; the flowers are large and of a deep rosy color, and arè borne in great profusion. We offer them in different colors, Rosea, red, pink and white.

Price of Weigelas, strong plants, 25c.

Althea (Rose of Sharon, Tree Hollyhock) - The Althea is a flowering shrub and is represented in many colors, the prevailing colors being white and bluishpurple. The Althea has been called by some the Tree Hollyhock, since its blossoms somewhat resemble those of the Hollyhock. When in full bloom the Althea is ablaze with blossoms. We have the Altheas in different colors, pink, purple, white, and pink and white. Price of strong plants, 25c. each.

Van Houtte -- The grandest of all the Spireas; it is a beautiful ornament for the lawn at any season; but when in flower it is a complete fountain of white bloom, the foliage. hardly showing. Perfectly hardy and an early bloomer. Price of strong plants $25 \mathrm{c}$.

Halleana. Hall's JAPAN HoneySUCKLE.-A strong, vigorous, almost evergreen sort, with pure white flowers. changing to yellow. Very fragrant, and covered with flowers from July to December; holds its leaves till January. The best bloomer of all. Price of strong plants 25c.
Deutzia, Pure Double White.-A variety having double flowers, which are white, tinged with pink, and which are produced in racemes from 4 to 5 inches long in great profusion.

Deutzia, Pride of Rochester-Is a variety raised and introduced by Ellwanger \& Barry, and blooms a week earlier than the other varieties. The flowers are large, double white, slightly tinged on the back of the petals with rose.

Deutzia Rosea-Red flowering, very attractive and should be included in every collection.

Prices of all of above varieties of Deutzias 20c. each.

Double White Lilac--This fine double flowering variety is of a pure snow white color Its flowers, which are composed of a number of corollas, are borne in enormous panicles, larger than other varieties. Price of strong plants 25c.

Lilac, Purple-The well known variety, one of the best. A good grower ; flowers and young wood fragrant ; purple.

Price of strong plants 25c.

California Privet-Makes one of the handsomest hedges imaginable. Wherever a close, compact hedge is desired we recommend California Privet Should be planted 8 or ro inches apart to give best results.

Price of strong plants $10 \mathrm{c}$. each, 75c. per dozen; $\$ 5$ per hundred.

\section{SUITABLE DISTANCES FOR PLANTING.}

Apples, Standard Apples, Dwarf.. ..30 to 40 feet ....... 8 to ro " Pears, Dtandard................. 8 8 to 20 " Peaches............................... 16 to 18 " Nectarines and Apricots....... 6 to 18 ". Cherries, Sweet................... 8 to 20 "“ Cherries, Sour.................... I 5 to I8 “ Plums. I6 to 20 Quinces.

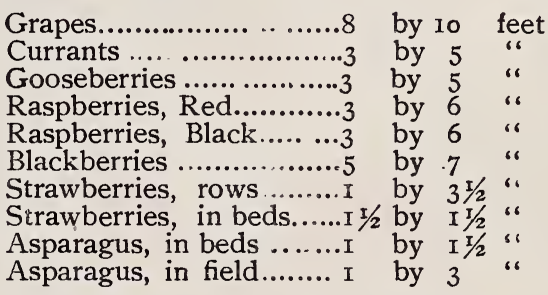

\section{NUMBER OF TREES OR PLANTS ON AN ACRE.}

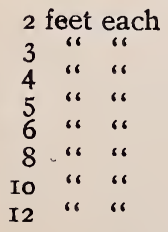

$$
\begin{array}{cc}
\text { way.... } \\
\text { 66 } & \ldots \\
\text { w6 } & \ldots \\
\text { 66 } & \ldots \\
\text { c6 } & \ldots \\
\text { 66 } & \ldots \\
\text { 6 } & \ldots
\end{array}
$$
Io, 890

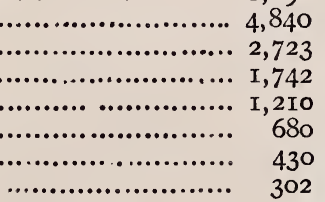

I5 feet each way.

$\begin{array}{lll}18 & \text { " } \\ 20 & \text { " } & \text { " } \\ 25 & \text { " } & \text { " } \\ 30 & \text { " } & \text { " } \\ 33 & \text { " } & \text { " } \\ 40 & & \end{array}$

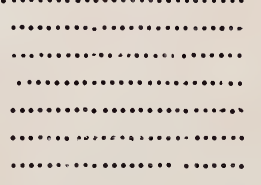

To ascertain the number of plants required to the acre at any given distance, divide the number of square feet $(43,560)$ in an acre by the number of square feet you desire to devote to each plant. For instance, in strawberries planted $\mathrm{I} / 2$ by 3 feet, each hill will occupy $4 \frac{1}{2}$ square feet, making 9,680 plants to the acre. 
These Seven Superb. Hardy, Two Year Old Roses

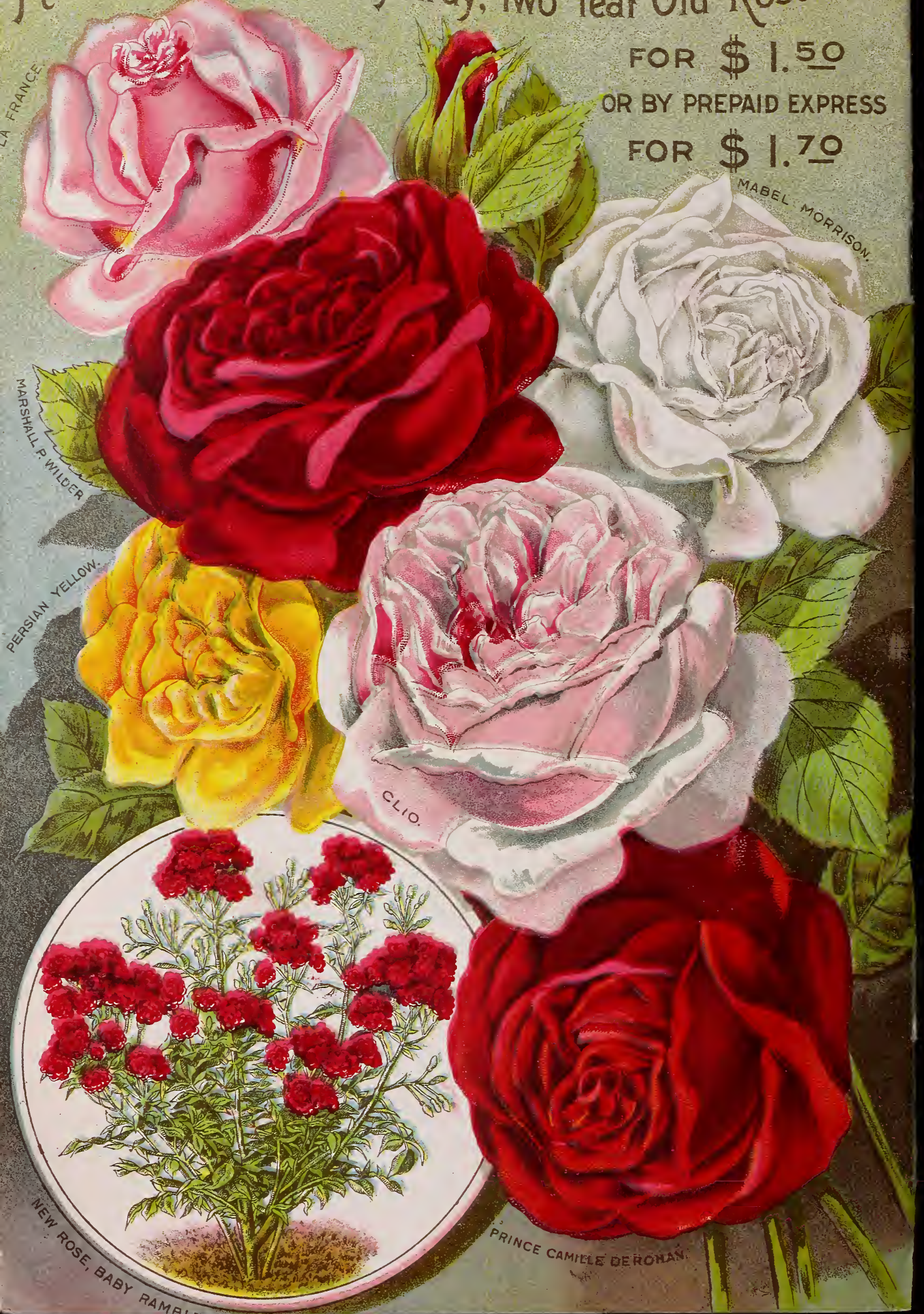

